\title{
Recent advances in the surgical care of breast cancer patients
}

\author{
Alessandra Mascaro, Massimo Farina, Raffaella Gigli, Carlo E Vitelli, Lucio Fortunato*
}

\begin{abstract}
A tremendous improvement in every aspect of breast cancer management has occurred in the last two decades. Surgeons, once solely interested in the extipartion of the primary tumor, are now faced with the need to incorporate a great deal of information, and to manage increasingly complex tasks.

As a comprehensive assessment of all aspects of breast cancer care is beyond the scope of the present paper, the current review will point out some of these innovations, evidence some controversies, and stress the need for the surgeon to specialize in the various aspects of treatment and to be integrated into the multisciplinary breast unit team.
\end{abstract}

\section{Introduction}

No other solid cancer has witnessed such a tremendous change and improvement in terms of diagnosis and management as breast cancer in the last 2 decades. This remains the most common cancer among women worldwide [1].

Breast cancer management has become increasingly complex, and requires a comprehensive assessment of multiple tasks in addition to the simple extirpation of the primary tumor, including breast imaging, advanced pathology, nuclear medicine and a variety of adjuvant therapies, both local and systemic. This has shifted breast cancer treatment into a multidisciplinary science.

Only a few decades ago, women with breast cancer were uniformly treated with radical mastectomy and total axillary dissection to achieve good loco-regional control and the possibility of full recovery. Conservative and selective surgical approaches to the breast and to the axilla, once viewed with scepticism, have now become standard of therapy for most patients $[2,3]$.

Earlier detection and more effective treatments have resulted both in an increasing percentage of small breast cancers found at the initial diagnosis and in a small decline in mortality [2].

Howewer, as the current goal for breast cancer patients is "conservation" instead "the more radical excision the better", the impact of local recurrence on

\footnotetext{
* Correspondence: Ifortunato@hsangiovanni.roma.it

Department of Surgery, Senology Unit, San Giovanni-Addolorata Hospital, Via Amba Aradam, 9, 00187 Rome, Italy
}

ject of research and debate.

The aims of this review are to analyze the most important changes which have occurred in the last several years in the surgical management of breast cancer patients and to review some relevant issues such as sentinel lymph node biopsy, the impact of local therapy on survival, and the aesthetic results.

Non Palpable Lesions and Localization Techniques

Breast cancer screening has dramatically increased the diagnosis of suspicious, non-palpable breast lesions, and therefore also the need to localize them in order to plan surgical treatment [4]. Furthermore, patients with a breast cancer removed with clear margins at the first excision seem to have a decreased risk of local recurrence compared with patients who need further re-excisions to achieve negative margins [5].

This represents a "hot" topic in breast surgery, since approximately $50 \%$ of breast cancers in modern surgical practices are non palpable, and this incidence is certainly destined to increase [6].

Today, pre-operative confirmation of malignancy is almost always achieved by fine-needle or core-biopsy, and therefore, we need to localize these small cancers to allow a one-step precise and directed excision.

Compared with their palpable counterpart, non-palpable lesions are associated with both a lower stage of disease and a substantially decreased incidence of lymph node involvement [7]. 
Wire localization (WL) is the most common technique used to identify small nodules, microcalcifications or parenchymal distorsions. Howewer, it has some disadvantages such as pain and discomfort in some patients, and occasionally carries risks of complications including dislodgement of the wire, intraoperative wire transection, retention of wire fragments, thermal injury with the use of cautery, hematoma and even syncope. WL is performed in most institutions as an additional procedure, outside the operating room, with further problems related to organization and scheduling.

Successful localization with free margins of resection is not always achieved with this technique and failures, with consequent re-excisions, are reported in up to $33 \%$ of cases [6-10].

A precise localization of a breast tumor with the wire is not always possible, and the angle of access and trajectory depends, in part, on the radiologist's ability. Furthermore, the introduction of the wire directly above the lesion may be technically problematic, especially under stereotaxic guidance in locations such as the inferior quadrants.

For this reasons several new techniques have been introduced in order to achieve breast tumor localization.

Radioguided occult lesion localization (ROLL) is a useful method to detect nonpalpable lesions through the injection of a nuclear tracer $(99 \mathrm{~m}$ TC-labelled colloidal albumin) directly around the tumor under ultrasound or stereotaxic guidance. Then, the excision of the primary tumor is guided by a gamma probe, and a sentinel node biopsy can be performed at the same time if needed [11-13].

Unlike the WL, the procedure is generally more straightforward and well tolerated, and the success rate is reported to be very high [14-23] (Table 1).

Although ROLL has been shown to be comparable to WL in at least 2 restrospective [24,25] and four prospective-randomized studies $[19,20,22,26]$ with regards to the

Table 1 Complete excision rate of non palpable lesions by ROLL

\begin{tabular}{lccc}
\hline Author & Year & N & Complete excision rate (\%) \\
\hline Gennari [14] & 2000 & 647 & 99 \\
\hline Tanis [15] & 2001 & 45 & 87 \\
\hline Ronka [16] & 2004 & 215 & 93 \\
\hline Thind [17] & 2005 & 68 & 84 \\
\hline Van Rijk [18] & 2007 & 293 & 89 \\
\hline Moreno [19] & 2008 & 61 & 93 \\
\hline Medina-Franco [20] & 2008 & 50 & 89 \\
\hline Lavouè [21] & 2008 & 72 & 85 \\
\hline Van Esser [22] & 2008 & 40 & 78 \\
\hline Sarlos [23] & 2009 & 100 & 98 \\
\hline
\end{tabular}

ability to identify the lesion, four reports have demonstrated a statistical difference in achieving tumor-free margins in favor of the former technique [17,24,26,27].

Another technique for localization of non-palpable breast tumors is represented by intraoperative ultrasound (IOUS).

It satisfies most requirements for an ideal technique to localize non-palpable breast tumors which are well visualized by ultrasound, while directing planes of surgery during the excision. This in turn is helpful in guaranteeing both negative margins and an adequate contour of resection in order to minimize the volume of excision.

Identification rate of non-palpable lesions and free margins of resection obtained through this procedure are extremely high [28-34] (Table 2).

Furthermore, microcalcifications, usually visible only by mammography, are sometimes associated with sonographic alterations that can be detected, and removal of such lesions under ultrasound guidance can sometimes be performed [35].

\section{Implications of Local Therapy}

As conservative approaches have developed in the last three decades and represent the standard of care for breast cancer patients around the world, the incidence of local recurrence (LR) has been widely studied. It occurs in $5-10 \%$ of patients at 10 years, and it is more pronounced in the first 3 or 4 years after primary surgery [36,37].

Although several factors have been associated with the risk of LR, at the multivariate analysis only age, status of surgical margins and postoperative radiotherapy seem to be independently correlated with it [38]. Patients with multifocal tumors, once uniformely thought to be associated with a higher risk of LR, and therefore treated with mastectomy, are now often offered breast conservation, when technically feasible, as most studies seem to indicate that the LR rate is not higher in these cases than previous reports for unifocal cancers [39]. Similarly, infiltrating lobular carcinoma is probably not associated with a higher incidence of LR compared to the ductal counterpart if resected with negative margins [40].

Table 2 Identification rate of small lesions by US

\begin{tabular}{lcccc}
\hline Author & Year & $\mathbf{N}$ & Identification (\%) & Free Margins (\%) \\
\hline Harlow [28] & 1999 & 65 & 100 & 97 \\
\hline Smith [29] & 2000 & 81 & 100 & 96 \\
\hline Kaufman [30] & 2003 & 100 & 100 & 90 \\
\hline Bennett [31] & 2005 & 103 & 100 & 93 \\
\hline Ngo [32] & 2007 & 70 & 96 & 94 \\
\hline Haid [33] & 2007 & 299 & 100 & 100 \\
\hline Fortunato [34] & 2008 & 77 & 100 & 97 \\
\hline
\end{tabular}


The influence of age on the risk of LR is striking, and many reports have shown that this is increased threefold for women less than 40 years of age [38,41-43]. Furthermore, younger patients show a statistically significant reduction of LR in several "boost trials", again demonstrating the importance of an appropriate local therapy particularly in this age group [44].

It is interesting to note that despite the widespread use of conservative approaches in breast cancer patients, there is no general agreement even on the definition of "negative" margins, and many describe such as the absence of tumor at the microscopic or inked margin, or with 1-3 mm clearance. It is clear that a high percentage of patients whose tumors are 2-5 $\mathrm{mm}$ from the radial margins have residual disease at re-excision [45]. For this reason, and despite best efforts, as many as 20$25 \%$ of patients in many institutions around the world return to the operating room after initial surgery for reexcision [46]. While many reports fail to describe a statistically significant impact of margins on LR, most would agree that one of the primary goals of conservative surgery is the removal of the primary tumor with a portion of normal breast tissue, so as to maintain a good breast shape [47-54].

Although the results of six prospective randomized trials in patients with invasive breast cancer have demonstrated that lumpectomy/quadrantectomy plus $\mathrm{RT}$ and mastectomy have equivalent survival results [55-60], it is worthwhile to remember that the first conservation trial, the Guy's wide excision study initiated in the 60's, has shown a decreased survival in the group treated conservatively [61]. This suggests that poor surgical removal of the primary tumor, possibly with dubious margins and without inking of the specimen, together with employment of suboptimal post-operative radiotherapy, may lead to a negative impact not only on local control but also on survival $[57,61]$.

Although additional retrospective data has been accumulated in the last few years suggesting that failure of local control has an impact on survival [62], the most striking evidence comes from the EBCTCG meta-analysis [63].

This has shown that adjuvant RT after BCS not only may improve local control, but it may also reduce 15year breast cancer mortality. The effect of radiation on LC seems more pronounced in node positive patients, while the effect on survival remains important both for node-negative and node-positive patients $[64,65]$.

This has lead many to suggest that for every four women for whom local failure is prevented, one life can be saved. As this disease is prevalent, and LR after quadrantectomy and radiation is far from being an exceptional event, this seems quite an important issue.
Minimalistic approaches are no longer viable for women with breast cancer, and the aim of the contemporary surgeon is to team up with all available specialists, and to coordinate efforts to reach the goal of local control.

\section{Skin Sparing Mastectomy}

Although breast conservation surgery (BCS) has become the gold standard for patients with early breast cancer, mastectomy remains an option and it is necessary in at least $20 \%$ of those women with multicentric tumors, widespread DCIS, and large or recurrent tumors [66]. Sometimes the risk of an unpleasant cosmetic result with conservative surgery to achieve tumor-free margins, or personal desire to avoid radiation therapy plays a role in the decision process.

New options are now available for these women and they represent the forefront of the surgical therapy for breast cancer patients.

Oncologic need to remove the skin envelope or the nipple-areola complex has never been proved, and has been lately challenged on solid evidence and background. Immediate breast reconstruction (IBR), a procedure once discouraged for some years after primary surgery because of fear of relapse, is now performed routinely for an increasing number of patients. This has a profoundly positive psychological effect, and allows for a more solid recovery of these women so touched by this disease [67].

Skin sparing mastectomy (SSM) has been increasingly used in the last 15 years to improve cosmesis because the skin envelope is preserved and the surgical access is limited to a small elliptical incision around the areola [68]. Our understanding that skin involvement is rare is corroborated by pathologic studies, and when present, it is usually over the primary tumor site, or is found in cases with advanced disease, skin tethering, or lymphatic emboli [69]. However, as maximal skin preservation is desirable, special technical considerations are to be addressed by the surgeon because the risk of leaving some glandular tissue behind can be as high $10 \%$ if skin flaps are more than $5 \mathrm{~mm}$ thick [70].

Clinical experience has confirmed so far that SSM has very acceptable results in terms of local control even in those studies with longer follow-up and is comparable to modified radical mastectomy both in terms of local control and survival [71-86] (Table 3).

Complications after SSM and immediate breast reconstruction are reported in about $15 \%$ of cases, and include flap necrosis and implant loss [87-89].

However, this risk must be weighed with the advantage in cosmetic result and in patient satisfaction (as defined by perception of body image, social activity and sexual aspects), because these outcomes are better in SSM with IBR compared with radical mastectomy [84]. 
Table 3 Recurrence Rates after SSM

\begin{tabular}{lcccc}
\hline Author & Year & N & LR (\%) & F/U (mo) \\
\hline Slavin [71] & 1998 & 51 & 2 & 45 \\
\hline Newman [72] & 1998 & 372 & 6 & 25 \\
\hline Simmons [73] & 1999 & 77 & 4 & 60 \\
\hline Kroll [74] & 1999 & 114 & 7 & 72 \\
\hline Rivadeneira [75] & 2000 & 71 & 6 & 49 \\
\hline Medina-Franco [76] & 2002 & 176 & 4 & 73 \\
\hline Foster [77] & 2002 & 67 & 4 & 49 \\
\hline Carlson [78] & 2003 & 565 & 5 & 65 \\
\hline Greenway [79] & 2005 & 225 & 2 & 49 \\
\hline Margulies [80] & 2005 & 50 & 0 & 8 \\
\hline Yano [81] & 2007 & 124 & 2 & 34 \\
\hline Patani [82] & 2008 & 83 & 0 & 34 \\
\hline Scholz [83] & 2008 & 72 & 0 & 42 \\
\hline Ueda [84] & 2008 & 74 & 5 & 50 \\
\hline Garwood [85] & 2009 & 64 & 1 & 13 \\
\hline Gerber [86] & 2009 & 238 & 10 & 101 \\
\hline
\end{tabular}

We favor IBR in almost all cases, and therefore routinely perform SSM to allow the plastic surgeon to intervene more comfortably at the same time. Sometimes, post-operative radiation therapy may be needed, and although several studies and current clinical recommendation report that the rate of complication is too high if an implant is inserted in this setting [74,90-92], in recent years a few studies have reassessed this issue [93-96]. We believe that this is still an option in selected cases, as it allows the patient to start more readily adjuvant systemic therapies if needed, and when it fails, it does not preclude or negatively influence possible autologus conversion or final outcome.

\section{Nipple-Sparing Mastectomy}

"Nipple sparing mastectomy" (NSM) is the ultimate challenge of this process which aims for an interaction between conservative techniques and radical surgery. In this procedure, the skin flap covering the breast gland and the nipple-areola complex (NAC) are preserved. In some cases the major ducts are removed.

In the past, the nipple has been routinely removed for fear of occult tumor involvement, although this has probably been overestimated. Many clinical studies have shown that this involvement varies from 6 to $23 \%$ depending on the size of the primary tumor, its location, multicentricity, lymph node positivity and the presence of extensive intraductal component [97-102] (Table 4).

We believe that this occurrence is rare in modern clinical practice and although the risk is real, patients can probably be safely selected for this approach.

Nevertheless, exact indications and contraindications to this procedure are not well defined, and the incidence of nipple involvement is reported to be as high as 50\%
Table 4 Occult Histologic Nipple Involvement

\begin{tabular}{lccc}
\hline AUTHOR & YEAR & PATIENTS (N) & NIPPLE INVOLVEMENT (\%) \\
\hline Santini [97] & 1989 & 1291 & 12 \\
\hline Laronga [98] & 1999 & 286 & 6 \\
\hline Sikand [99] & 2005 & 220 & 7 \\
\hline Vlajciz [100] & 2005 & 108 & 23 \\
\hline Petit [101] & 2006 & 106 & 10 \\
\hline KG [102] & 2008 & 397 & 15 \\
\hline
\end{tabular}

for tumors measuring more than $4 \mathrm{~cm}$ or located closer than $2 \mathrm{~cm}$ from the nipple [103]. Therefore, the best candidates for NSM are patients with no large tumor (T1-T2), with lesions at least $1 \mathrm{~cm}$ from the areola or 2 $\mathrm{cm}$ from the nipple, or small multicentric carcinomas [101].

Furthermore, nipple involvement is rare if the retroareolar margin is free of disease [104].

A strategic issue is to avoid partial or total nipple or areola necrosis because, although this can be easily treated postoperatively and under local anesthesia, it results in psychological distress to the patient, and it must be considered a failure of the procedure itself.

The rate of nipple necrosis varies from 0 to $15 \%$ [101,105-110] (Table 5).

Surgical technique is extremely important. It is now well understood that the use of periareolar incisions should be abandoned, as it negatively affects the vascular supply of the nipple-areola complex, and that either a radial or a lateral incision seem to be more effective in this regard [109].

Although it is not clear how much tissue can or should be left under the NAC, or if "nipple coring" (removal of the terminal ducts from the inside of the nipple papilla) should be performed (and how aggressively), results of NSM can been examined in a few retrospective studies published so far, and the local recurrence rate is shown to be quite low in the majority of them [103,106,107,110-115] (Table 6).

The role of post-operative radiotherapy following NSM is unknown at the present, although a three-fold decrease in the rate of locoregional failure has been reported in one series [116]. However, in this retrospective study only large tumors $(>3 \mathrm{~cm})$ were included, and the site of failure is not clearly described.

Proponents at the European Institute of Oncology have recently updated their experience reporting on 1,001 patients treated with a single intra-operative radiotherapy treatment (21 Gy) with electrons (ELIOT) to the NAC after NSM in the assumption that this single radiation dose may sterilize occult cancer foci eventually left in the glandular tissue behind the areola [115]. This is the largest experience with NSM, to date, and the incidence of local recurrence is reported at $1.4 \%$ with a 
Table 5 Nipple Necrosis after NSM

\begin{tabular}{llllc}
\hline AUTHOR & YEAR & N & PARTIAL NECROSIS \% & TOTAL NECROSIS \% \\
\hline Crowe [105] & 2004 & 48 & 6 & 0 \\
\hline Caruso [106] & 2006 & 50 & 2 & 0 \\
\hline Sacchini [107] & 2006 & 192 & 7 & 4 \\
\hline Petit [101] & 2006 & 106 & 10 & 5 \\
\hline Komorowski [108] & 2006 & 38 & 5 & 8 \\
\hline Stolier [109] & 2008 & 82 & 0 & 0 \\
\hline Voltura [110] & 2008 & 51 & 6 & 0 \\
\hline
\end{tabular}

median follow-up of 20 months. Although some concerns have been raised regarding the possible negative effects (even long-term) on the vascularity of the NAC after a single large dose of radiotherapy, the usefulness of this approach is appealing but currently unproven. Of interest, in a subgroup of patients, treated with ELIOT, with very close tumor margins under the areola, no local recurrence was observed.

\section{Oncoplasty}

Oncoplasty has been developed in the last 15 years as a new surgical approach and incorporates a variety of relatively simple, common plastic techniques. This has generated much enthusiasm around the world, among both by breast and plastic surgeons, and in the UK formal oncoplasty training has been developed [117].

Indeed, oncoplastic surgery represents a step forward in breast conservation, allowing us to treat tumors in problematic locations (for example in the lower quadrants), to avoid poor cosmetic results, asymmetry or unpleasant scarring in the upper quadrants, and to obtain wider excisions and tumor free margins [118].

Oncoplasty is safe, as no statistical differences in terms of local relapse and disease-free survival are evidenced when comparing classic quadrantectomies and oncoplastic approaches [118-120]. It should be considered for those patients where adequate local excision cannot be achieved without a significant risk of local deformity, as it frequently occurs in resection of more than $20 \%$ of breast volume, or for tumors located in the central, medial or inferior quadrants. Other indications include women considering a breast reduction in addition to excision.

Several volume displacement techniques can be employed, including glandular remodelling, inferior or superior pedicle flaps, round block excision, and the Grisotti flaps. Their description is beyond the scope of this review.

Centrally located tumors account for 5 to $20 \%$ of breast cancer cases and have long been thought to be associated with a higher incidence of multicentricity and multifocality [121,122]. However, other more recent reports have failed to substantiate a specific correlation between location of the tumor and multicentricity $[123,124]$. For this reason, they represent an important challenge for breast surgeons, as they have been classically treated with a mastectomy, and until few years ago only $7 \%$ of central breast cancers were treated with conservative surgery [119].

Several studies on the local recurrence rate after central quadrantectomy, each with a small number of patients, show very acceptable results even long-term [125-132] (Table 7).

A direct comparison between central quadrantectomy and mastectomy has seldom been studied, and no significant differences in terms of local failure and overall survival have been reported [119,127,133-135]. However, these reports are limited by their retrospective nature and may not be comparable because mastectomy was

Table 6 Nipple Sparing Mastectomy: Local Recurrence

\begin{tabular}{lllll}
\hline AUTHOR & YEAR & N & LOCAL RECURRENCE \% & FOLLOW-UP (months) \\
\hline Simmons [111] & 2004 & 17 & 0 & 24 \\
\hline Caruso [106] & 2006 & 50 & 2 & 66 \\
\hline Sacchini [107] & 2006 & 123 & 2 & 25 \\
\hline Denewer [112] & 2007 & 41 & 0 & 8 \\
\hline Crowe [113] & 2008 & 149 & 3 & 41 \\
\hline Voltura [110] & 2008 & 51 & 6 & 18 \\
\hline Sookhan [103] & 2008 & 18 & 0 & 11 \\
\hline Gerber [114] & 2009 & 61 & 12 & 101 \\
\hline Petit [115] & 2009 & 1001 & 1.4 & 20 \\
\hline
\end{tabular}


Table 7 Local Recurrence after Central Quadrantectomy

\begin{tabular}{lcccc}
\hline AUTHOR & YEAR & $\mathbf{N}$ & LR $\%$ & FOLLOW-UP (Months) \\
\hline Galimberti [125] & 1993 & 37 & 0 & 32 \\
\hline Haffty[126] & 1995 & 98 & 6 & 108 \\
\hline Simmons[127] & 2001 & 32 & 6 & 60 \\
\hline Pezzi[128] & 2004 & 15 & 6 & 32 \\
\hline Tausch [129] & 2005 & 44 & 7 & 51 \\
\hline Naguib [130] & 2006 & 23 & 9 & 13 \\
\hline Huemer[131] & 2007 & 31 & 0 & 34 \\
\hline Wagner [132] & 2007 & 31 & 0 & 42 \\
\hline
\end{tabular}

usually performed for larger tumors. Only one prospective non-randomized study has been published so far, and it has confirmed an equivalent outcome in terms of local or systemic disease [132].

We believe that by adhering to the principles of breast-conserving surgery, including complete resection of the primary tumor with a negative margin, these centrally located tumors can be treated adequately by nipple-areolar resection. Adjuvant radiation therapy to the remainder of the breast can treat subclinical microscopic disease, if present, with accepTable local control and adequate cosmesis.

Sentinel Lymph node Biopsy, and Management of Special Circumstances

Lymph node involvement is the single most important prognostic factor for survival in breast cancer patients, and consequently information about it provide both staging information and guidance regarding treatment options [136].

SLN biopsy is now considered an adequate axillary staging procedure for patients who have breast cancer because it is easy and reproducible if carried out by experienced clinicians, and carries less morbidity compared to axillary node dissection [137].

Many concerns were raised in the past because SLN biopsy can result in some false-negative cases. A recent meta-analysis of 69 trials found the rate of false negatives to be about $7 \%$ of the node-positive patients [138].

Much of what is known today regarding SLN biopsy in breast cancer does not result from randomized trials. The procedure has been accepted quickly by most dedicated surgeons around the world on the basis of a growing body of evidence that SLN is effective. Often, patient demand has overcome the caution that surgeons usually demonstrate before abandoning a well-tested procedure, such as axillary node dissection. In some cases, randomized trials have been prematurely closed because of problems in accrual, either because randomization was not acceptable to patients, or because surgeons, after acquiring sufficient experience with SLN biopsy, were unwilling to allow their patients to enter the trial.
Enhanced pathology of the SLN has generated much confusion and even controversy, but it is a key point as different results can be obtained by different groups using different protocols. A survey of the European Working Group for Breast Screening Pathology reported that 240 pathologists replying to a questionnaire described some 123 different pathology protocols [139].

The authors' group recently has proposed a simple, practical standardized protocol, with slicing at three levels at 100-micron intervals and double staining with both hematoxylin and eosin (H\&E) and immunohistochemistry (MNF116) (Figure 1) [140]. This protocol has allowed our pathologists to increase the diagnosis of additional nodal disease by nearly two-thirds compared with standard, single-section analysis of the lymph nodes stained with H\&E, although the majority of this gain is represented by minimal disease, micrometastases or isolated tumor cells. (Figure 1)

Some important issues, such as the prognostic influence of SLN micrometastases, and the use of SLN biopsy in special circumstances are still subject of open debate among clinicians.

The prognostic significance of micrometastases in SLN is controversial. Its diagnosis is rapidly increasing (17\% per annum since 1997 ) as reported by a recent analysis of the SEER database of 175,000 patients treated between 1990 and 2002 [141]. This probably results from a combination of factors, including the diagnosis of smaller tumors by mammographic screening, and the implementation of SLN biopsy with more frequent diagnosis of minimal node involvement by step sectioning.

In the most important retrospective study, conducted by the International (Ludwig) Breast Cancer Study Group, 9\% of 921 patients who had negative axillary lymph nodes on routine $H \& E$ single-section analysis were found to be node positive on serial sectioning [142]. In some, but not in all, groups these women had a significantly poorer 5 -year disease-free and overall survival rate. Recent data seem to confirm the hypothesis that micrometastases are indeed a marker of poorer prognosis.

In a review of the published literature in 1997, Dowlatshahi [143] analyzed all large and long-term studies and confirmed a statistically significant decrease in survival associated with the presence of axillary node micrometastases. The group at Memorial Sloan Kettering Cancer Center has used serial sections and immunohistochemistry to re-evaluate all axillary lymph nodes from 373 patients operated in the 1970s who were deemed to be node negative by routine histopathology [144]. The presence of any detectable micrometastatic disease was associated with decreased disease-free and overall survival rates. 
Sentinel lymph nodes are divided at the longitudinal axis and intraoperative examination obtained with touch prep cytology
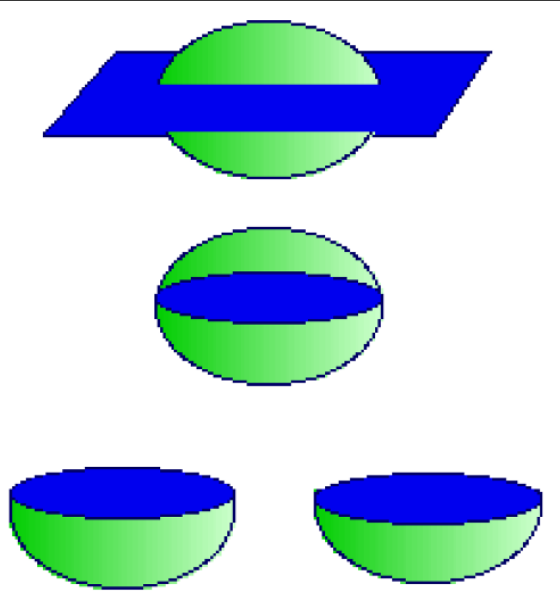

$\downarrow$

Lymph nodes are paraffin embedded

\section{First section LEVEL 0}
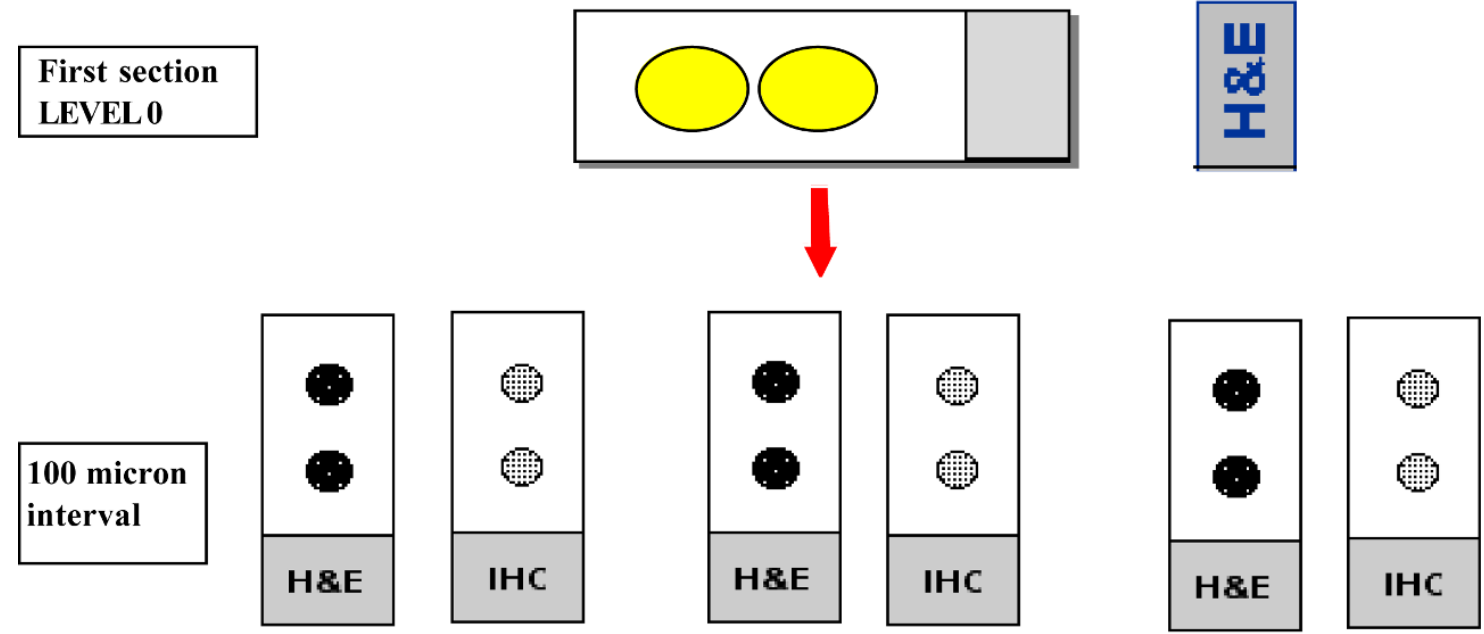

\section{Level 1}

\section{Level 2}

Level 3

Figure $1 \mathrm{~A}$ simple and standardized protocol, with slicing at three levels at 100-micron intervals and double staining with both hematoxylin-eosin and immunohistochemistry, that has allowed the pathologists in the authors' group to diagnose additional nodal disease with an increment of nearly two thirds compared with standard, single-section analysis of the lymph nodes stained with hematoxylin-eosin. (Adapted from Fortunato L, Amini M, Costarelli L, et al. A standardized sentinel lymph node enhanced pathology protocol (SEPP) in patients with breast cancer. J Surg Oncol 2007;96[6]:471; with permission.) 
In a review of 1959 cases treated at the European Institute of Oncology from 1997 to 2000, Colleoni and colleagues [145] have found that minimal involvement (micrometastases or isolated tumor cells) of a single lymph node correlated with decreased disease-free survival and doubled the risk of distant metastases.

Recently, the presence of isolated tumor cells or micrometastases in the SLN were found to be associated with a reduced 5-year disease-free survival among 856 women in the Netherlands with favorable early-stage breast cancer who did not receive adjuvant therapy. In this study, an additional cohort of 995 patients who received adjuvant therapy showed an improved diseasefree survival at a median follow-up of five years [146].

At the present time, surgical management and systemic options in case of SLN micrometastases are controversial. Most retrospective studies have reported a substantial rate of additional lymph node metastases in patients with SLN micrometastases, with a wide range between reports, making one think that patient selection is a key in determing the choice of candidates for completion lymph node dissection [147-154] (Table 8).

Ongoing or completed/closed randomized trials such as the ACOSOG Z0010, the National Surgical Adjuvant Breast and Bowel Project B32 and the International Breast Cancer Study Group 23-01, will help to fully understand whether further axillary treatment should be mandatory when the SLN is positive [155-157].

There are still a few clinical settings in which SLN biopsy generates controversy, and we would like to review some of them:

\section{Ductal Carcinoma In Situ (DCIS)}

Management of DCIS is clinically relevant, because its incidence is increasing and represents today approximately $20-25 \%$ of newly diagnosed cases of breast cancer [158].

Traditionally, axillary node metastases were identified by conventional histology in fewer than $2 \%$ of patients whose surgical specimen was interpreted as containing DCIS only, probably because the presence of invasive cancer can be unrecognized [159].
Studies of patients with "pure" DCIS who have undergone SLN biopsy have confirmed an extremely low rate of axillary node involvement [160,161]. Unfortunately, the diagnosis of "pure" DCIS can be misleading because microinvasion can be missed even with an extensive histologic search and immunostaining, and because a preoperative diagnosis is not always feasible due to sampling error after microbiopsy. A recent meta-analysis, including 22 published reports, has estimated that the incidence of SLN metastases in patients with a preoperative diagnosis of DCIS is $7.4 \%$, compared with an incidence of $3.7 \%$ for patiens with a definitive (postoperative) diagnosis of DCIS [162].

In DCIS with diagnosed microinvasion the incidence of axillary metastases has been reported to range from $3 \%$ to $10 \%$ in small series [163-173] (Table 9).

In case of SLN involvement after diagnosis of DCIS, it is not clear whether a complete axillary node dissection should be performed, or additional systemic therapy be considered. A review of 21 series collected only 29 such patients undergoing axillary lymphadenectomy after a positive SLN finding, and no additional metastases were found after completion of lymphadenectomy [174].

\section{Recurrent Breast Cancer}

Approximately $10 \%$ of breast cancer patients are expected to experience an ipsilateral recurrence 10 to 15 years after their initial treatment.

Although patients who have an ipsilateral recurrence of breast cancer are at increased risk of systemic relapse, their prognosis is not uniformly bad, and approximately two thirds of patients are alive at 5 years [175]. Until recently, axillary re-evaluation was not indicated in these cases.

Recent studies, however, have suggested that a repeat SLN can be performed after a previous SLN biopsy, and sometimes after an axillary node dissection. This has the potential to alter clinical management, as it may help to stratify the risk of systemic disease, and to consider the need of additional systemic therapies.

For a recurrent breast cancer, a repeat SLN biopsy seems more successful after a previous SLN biopsy than

Table 8 Additional Positive Non Sentinel Metastases for Micrometastatic SLN

\begin{tabular}{llllc}
\hline AUTHOR & YEAR & SLN (N) & MICROMETASTASES (\%) & POSITIVE NON-SLN (\%) \\
\hline Reynolds [148] & 1999 & 220 & 27 & 22 \\
\hline Turner [149] & 2000 & 514 & 42 & 22 \\
\hline Nos [150] & 2003 & 800 & 33 & 7 \\
\hline Hwang [151] & 2003 & 627 & 21 & 57 \\
\hline Fan [152] & 2005 & 390 & 29 & 17 \\
\hline Rutledge [153] & 2005 & 358 & 25 & 3 \\
\hline Schrenk [154] & 2005 & 966 & 39 & 18 \\
\hline Van Rijk[155] & 2006 & 2150 & 30 & 19 \\
\hline
\end{tabular}


Table 9 SLN Biopsy in DCIS with Microinvasion

\begin{tabular}{lccc}
\hline AUTHOR & YEAR & $\mathbf{N}$ & SLN POSITIVITY (\%) \\
\hline Zavatosky [164] & 1999 & 14 & 4 \\
\hline Klauber-De More [165] & 2000 & 31 & 3 \\
\hline Wassergerg [166] & 2002 & 57 & 3 \\
\hline Intra [167] & 2003 & 41 & 10 \\
\hline Le Bouedec [168] & 2005 & 107 & 7 \\
\hline Sakr [169] & 2006 & 128 & 7 \\
\hline Zavagno [170] & 2007 & 43 & 9 \\
\hline Fortunato [171] & 2007 & 77 & 8 \\
\hline Doyle [172] & 2009 & 145 & 5 \\
\hline Rubio [173] & 2009 & 47 & 4 \\
\hline Polom [174] & 2009 & 183 & 5 \\
\hline
\end{tabular}

after an axillary node dissection, and in this setting SLN positivity is not uncommon [176-185] (Table 10).

The risk of an extra-axillary localization (parasternal, interpectoral, or supraclavicular region or to the contralateral axilla) is reported in approximately one-third of cases, particularly after a previous AND.

\section{Neoadjuvant Chemotherapy}

An area of particular interest is the use of SLN biopsy in patients undergoing neoadjuvant chemotherapy, because the number of patients choosing this option is increasing.

Until recently, feasibility and accuracy of SLN biopsy in these patients were considered limited due to the possible alteration of lymphatic patterns after chemotherapy, but several studies have reached different conclusions.

Data reported in the literature show an identification rate from 71 to $100 \%$ and a false-negative rate less than 13\% [186-205] (Table 11).
Our group, however, favors SLN biopsy before beginning of neoadjuvant therapy, as pathologic stage, along with complete response, are still the most important prognostic factors for these patients who so frequently belong to a young age group. Securing stage allows a more precise knowledge of the risk for the single patient; it allows meaningful comparison between different neoadjuvant protocols; and in case of negativity, it allows a simple tumorectomy after therapy for those patients with good responses.

\section{Multicentric Breast Cancers}

Multicentric breast cancer may occur in up to $10 \%$ of cases. SLN biopsy is also accurate in these patients, because SLN drains the whole breast, regardless of tumor localization, as reported by many studies [206-216] (Table 12).

In the largest report to date, a study from the Austrian Sentinel Node Study Group, a retrospective comparison between 142 patients with multicentric and 3,216 patients with unicentric cancers, showed no difference in detection of the SLN, or false-negative rates [211]. Therefore, we believe that SLN should be considered standard of care for these tumors.

Although either multiple Tc-99 injections or a single intradermal injection over the largest-size lesion has been described, a single periareolar injection of the tracer has been proposed as a mean to simplify this technical aspect, and there evidence that this leads to the identification of a single, representative SLN [212].

Internal Mammary SIn Biopsy

Although prospective randomized trials have not demonstrated a therapeutic benefit of removal of internal mammary lymph nodes (IMN) in patients with breast cancer [217], it is well known that involvement of

Table 10 SLN in Recurrent Breast Cancer

\begin{tabular}{|c|c|c|c|c|c|c|}
\hline Author & Year & $\mathbf{N}$ & $\begin{array}{c}\text { Success after previous SLND } \\
(\%)\end{array}$ & $\begin{array}{c}\text { Success after previous ALND } \\
(\%)\end{array}$ & $\begin{array}{l}\text { Extra-axillary localization of SLN } \\
(\%)\end{array}$ & $\begin{array}{l}\text { Positive SLN } \\
(\%)\end{array}$ \\
\hline Sood [177] & 2004 & 4 & - & $4 / 4$ & $2 / 4$ & $0 / 4$ \\
\hline $\begin{array}{l}\text { Agarwa I } \\
{[178]}\end{array}$ & 2005 & 2 & - & $2 / 2$ & $2 / 2$ & $1 / 2$ \\
\hline $\begin{array}{l}\text { Roumen } \\
{[179]}\end{array}$ & 2006 & 12 & $2 / 2$ & $8 / 10$ & $7 / 12$ & $4 / 10$ \\
\hline $\begin{array}{l}\text { Newman } \\
{[180]}\end{array}$ & 2006 & 8 & $1 / 8$ & $7 / 7$ & $10 / 10$ & $0 / 7$ \\
\hline Taback [181] & 2006 & 15 & $5 / 6$ & $6 / 9$ & $8 / 15$ & $3 / 11$ \\
\hline Intra [182] & 2007 & 65 & $65 / 65$ & - & $5 / 63$ & $7 / 63$ \\
\hline Port [183] & 2007 & 46 & - & $22 / 46$ & $13 / 46$ & $10 / 64$ \\
\hline Barone [184] & 2007 & 19 & $6 / 7$ & $0 / 12$ & $16 / 19$ & $2 / 16$ \\
\hline $\begin{array}{l}\text { Axelsson } \\
\text { [185] }\end{array}$ & 2007 & 46 & - & $22 / 46$ & $13 / 46$ & $7 / 22$ \\
\hline Koizumi [186] & 2008 & 31 & $3 / 31$ & $16 / 31$ & $14 / 23$ & $4 / 28$ \\
\hline TOTAL & & 248 & $82 / 119$ (69) & $87 / 167(52)$ & $90 / 240(37)$ & $38 / 227$ (17) \\
\hline
\end{tabular}


Table 11 Sentinel Lymph node biopsy after neoadjuvant chemotherapy

\begin{tabular}{llllc}
\hline Author & Year & N & Identification rate (\%) & False-negative rate (\%) \\
\hline Breslin [187] & 2000 & 51 & 84 & 13 \\
\hline Tafra [188] & 2001 & 29 & 93 & 0 \\
\hline Fernandez [189] & 2001 & 40 & 85 & 22 \\
\hline Julian [190] & 2002 & 34 & 91 & 0 \\
\hline Stearns [191] & 2002 & 34 & 85 & 23 \\
\hline Brady [192] & 2002 & 14 & 93 & 0 \\
\hline Schwartz [193] & 2003 & 21 & 100 & 9 \\
\hline Piato [194] & 2003 & 42 & 98 & 12 \\
\hline Reitsamer [195] & 2003 & 30 & 87 & 7 \\
\hline Kang [196] & 2004 & 54 & 72 & 11 \\
\hline Lang [197] & 2004 & 53 & 94 & 4 \\
\hline Shimazu [198] & 2004 & 47 & 94 & 12 \\
\hline Balch [199] & 2004 & 32 & 97 & 5 \\
\hline Mamounas [200] & 2005 & 428 & 85 & 12 \\
\hline Tausch [201] & 2006 & 167 & 85 & 8 \\
\hline Newman [202] & 2007 & 54 & 98 & 8 \\
\hline Shen [203] & 2007 & 69 & 93 & 25 \\
\hline Kinoshita [204] & 2007 & 104 & 91 & 10 \\
\hline Hino [205] & 2008 & 55 & 90 & 0 \\
\hline Classe [206] & 2009 & 195 & 11 \\
\hline TOTAL & & & $68 / 538(13 \%)$ \\
\hline
\end{tabular}

this chain is associated with worse prognosis. Furthermore, medial and inferior tumors have been reported to drain more commonly to IMN [218], although this has not been routinely taken in consideration in the last decades. Indeed, the IMN represents an important pathway, draining lymphatics from the deep breast lobules along the pectoral fascia and intercostals muscles [219].

Several studied have shown that SLN biopsy of the IMN is feasible, although it requires mapping through a deep intraparenchimal or peritumoral injection, as IMN identification is almost impossible after an intradermal injection [220,221]. The procedure involves more commonly a direct exposure of the second or third intercostal space, division of the intercostal muscle fibers, and is associated with the rare possibility of breach of the pleural cavity [222]. This has raised concerns regarding the acceptability of this procedure if there is no definitive demonstration of a survival benefit.

Studies have evidenced that SLN of IMN can be identified in $8-34 \%$ of breast cancer patients, and it can potentially benefit $7-15 \%$ of such patients because of a positive histologic finding [220,222-226]. Therefore, a

Table 12 SLN biopsy in multicentric breast cancers

\begin{tabular}{lllcc}
\hline Author & Year & N & Identification rate (\%) & False negative rate (\%) \\
\hline Schrenk [207] & 2001 & 19 & 100 & 0 \\
\hline Fernandez [208] & 2002 & 53 & 98 & 0 \\
\hline Kumar [209] & 2003 & 59 & 93 & 0 \\
\hline Tousimis [210] & 2003 & 70 & 96 & 8 \\
\hline Goyal [211] & 2004 & 75 & 95 & 9 \\
\hline Knauer [212] & 2006 & 150 & 91 & 4 \\
\hline Ferrari [213] & 2006 & 31 & 100 & 8 \\
\hline Gentilini [214] & 2006 & 42 & 100 & NR \\
\hline D'Eredita [215] & 2007 & 30 & 100 & 6 \\
\hline Cipolla [216] & 2008 & 34 & 100 & 0 \\
\hline Lo Yf [217] & 2009 & 135 & $666 / 698(95 \%)$ & 0 \\
\hline TOTAL & & 698 & $11 / 190$ (6\%)
\end{tabular}


potential change in management in the whole group is uncommon.

In case of IMN positivity adjuvant radiotherapy or systemic therapy may be offered, and clinical trials would be needed to determine whether it improves survival.

\section{Breast Units: A Challenge For The Clinician}

In the past, a few studies [227-234] have analyzed various high-risk surgical procedures (such as pancreatic or hepatic surgery) and correlated post-operative outcomes to hospital or surgeon procedure volume. The results of these studies have strongly suggested that complex visceral resections ought to be regionalized and concentrated in high volume hospitals.

Surprisingly, this rule may also apply to breast cancer care, because even if the surgical skills required in most cases are not usually complex, the need for a comprehensive, multidisciplinary management does seem to play a difference. This has prompted a debate regarding how to guarantee women with the best care possible through a preferential access to specialized breast cancer centers.

An analysis of some 233,000 operated breast cancer patients extracted from a nationwide US database and operated over a 13-year period has shown that the risk of death was three times higher for patients treated at low-volume hospitals, and that they were less likely to receive breast conservation. Furthermore, the risk of post-operative complications was higher and length of stay was longer in this group [235].

A review of 24,834 patients from the Florida Cancer Data System reported higher survival rates for patients treated at teaching hospitals compared with community or low-volume hospitals $[235,236]$. It was concluded that much of these differences were due to the decreased use of proven adjuvant therapies, again underlining the need for an integrated treatment for this disease.

Not only hospital volume and type, but also surgeons' experience, do make a difference. In a report of almost 30,000 patients operated in the Los Angeles County, treatment by a surgical oncologist (a "specialist") resulted in a $33 \%$ reduction in the risk of death at 5 years at the multivariate analysis [237].

In the US this information has resulted in a rapid increment of Breast Fellowship, recognizing that appropriate training is one of the key factors in improving quality of care. Currently, the number of such subspecialties almost equals that for surgical oncology. Nevertheless, until few years ago $25 \%$ of surgeons in the US performed almost $90 \%$ of the surgery for breast cancer, and probably this occurs even more frequently around the world [238].

In Europe, the Florence and Hamburg $[239,240]$ statements have anticipated these findings as early as 1988 , and, through a joint effort of EORTC, the European Society of Mastology (EUSOMA) and Europa Donna, the innovative concept for standard guidelines of Breast Units has been proposed to assure the best quality of care to women with breast cancer.

The EUSOMA "Requirements of a Specialist Breast Unit" was first published in 2000 and sets mandatory criteria for accreditation. This revolutionary concept is based on a process of voluntary accreditation; it was established because hospitals will likely be eager to claim that they have specialized breast units, and specialists will wish to show that they work in recognized units.

Requirements for accreditation indicate the need of one Breast Unit every 250,000 total population, and include at least 150 new cases of breast cases diagnosed each year, a core team in which each member must have special training in breast cancer (surgeon, radiologist, oncologist, pathologist, patient support staff, data managers, psychologist, genetist), regular multidisciplinary case management meetings, and adequate treatment facilities for patients.

We now know that a service provided by a trained specialist is more efficient and more cost effective; diagnostic decisions are made earlier and unnecessary investigations avoided; operations conducted by specialists produce better results for technical reasons; the interpretation of imaging techniques and the reading of histology is much more likely to produce definitive opinions if carried out by experts.

All this is leading towards a radically different type of organization for the treatment of breast cancer. This change will be driven not much from "mandatory" requirements, but by the willingness of more sophisticated breast cancer patients to search for the most appropriate treatment and the best possible results.

\section{Conclusions}

The "new era" of breast cancer treatment began more three decades ago with the revolutionary concept of breast conservation, and has not yet finished.

Clinical research, multidisciplinary approaches, and sophisticated therapies are being sought by every women newly diagnosed with breast cancer and hopefully will be more accessible so we can improve the overall quality of care for breast cancer treatment.

Surgeons must keep up with this process, and lead future changes to reach the goal of complete recovery for every patient.

\section{Authors' contributions}

All Authors participated in the design and coordination of the study, read and approved the final manuscript. 


\section{Competing interests}

The authors declare that they have no competing interests.

Received: 29 June 2009

Accepted: 20 January 2010 Published: 20 January 2010

\section{References}

1. Jemal A, Siegel R, Ward E, Hao Y, Xu J, Murray T, Thun MJ: Cancer statistics. CA Cancer J Clin 2008, 58:71-96.

2. Veronesi U, Cascinelli N, Mariani L, Greco M, Saccozzi R, Luini A, Aguilar M, Marubini E: Twenty-year follow-up of a randomized study comparing breast-conserving surgery with radical mastectomy for early breast cancer. N Engl J Med 2002, 347:1227-32.

3. Fisher B, Anderson S, Redmond CK, Woolmer N, Wickersham DL, Cronin WM: Reanalysis and results after 12 years of follow-up in a randomized clinical trial comparing total mastectomy with lumpectomy with or without irradiation in the treatment of breast cancer. N Engl J Med 1995, 333:1456-61.

4. Tabard L, Yen MF, Vita B, Chen HH, Smith RA, Duffy SW: Mammography service screening and mortality in breast cancer patients: 20-year followup before and after introduction of screening. Lancet 2003, 361:1405-10.

5. Menes TS, Tartter Pl, Bleiweiss I, Godbold JH, Seabrook A, Smith SR: The consequence of multiple re-excisions to obtain clear lumpectomy margins in breast cancer patients. Ann Surg Oncol 2005, 12:881-5.

6. Rahusen FD, Bremers AJ, Fabry HF, van Amerongen AH, Boom RP, Meijer S: Ultrasound-guided lumpectomy of nonpalpable breast cancer versus wire-guided resection: a randomized clinical trial. Ann Surg Oncol 2002, 9:994-8.

7. Gøtzsche PC, Nielsen M: Screening for breast cancer with mammography. Cochrane Database Syst Rev 2006, 18:CD001877.

8. Jortay AM, Daled H, Faverly D: Contribution of hook-guided breast biopsy to the pathological diagnosis of mammographic lesions. Acta Chir Belg 1999, 99:26-9.

9. Rissanen TJ, Mäkäräinen HP, Mattila SI, Karttunen Al, Kiviniemi HO, Kallioinen MJ, Kaarela OI: Wire localized biopsy of breast lesions: a review of 425 cases found in screening or clinical mammography. Clin Radiol 1993, 47:14-22.

10. Mokbel K, Ahmed M, Nash A, Sacks N: Re-excision operations in nonpalpable breast cancer. J Surg Oncol 1995, 58:225-8.

11. Intra M, de Cicco C, Gentilini O, Luini A, Paganelli G: Radioguided localisation (ROLL) of non-palpable breast lesions and simultaneous sentinel lymph node biopsy (SNOLL): the experience of the European Institute of Oncology. Eur J Nucl Med Mol Imaging 2007, 34:957-8.

12. Ricart Selma V, González Noguera PJ, Camps Herrero J, Martínez Rubio C, Lloret Martí MT, Torregrosa Andrés A: US-guided localization of nonpalpable breast cancer and sentinel node using 99 mTechnetiumalbumin colloid]. Radiologia 2007, 49:329-34.

13. Lavoué V, Nos C, Clough KB, Baghaie F, Zerbib E, Poulet B, Lefrère Belda MA, Ducellier A, Lecuru F: Simplified technique of radioguided occult lesion localization (ROLL) plus sentinel lymph node biopsy (SNOLL) in breast carcinoma. Ann Surg Oncol 2008, 15:2556-61.

14. Gennari R, Galimberti V, De Cicco C, Zurrida S, Zerwes F, Pigatto F, Luini A, Paganelli G, Veronesi U: Use of technetium-99 m-labeled colloid albumin for preoperative and intraoperative localization of nonpalpable breast lesions. J Am Coll Surg 2000, 190:692-8.

15. Tanis PJ, Deurloo EE, Valdés Olmos RA, Rutgers EJ, Nieweg OE, Besnard AP, Kroon BB: Single intralesional tracer dose for radio-guided excision of clinically occult breast cancer and sentinel node. Ann Surg Oncol 2001, 8:850-5.

16. Ronka R, Krogerus L, Leppanen E, von Smitten K, Leidenius M: Radioguided occult lesion localization in patients undergoing breastconservin surgery and sentinel node biopsy. Am J Surg 2004, 187:491-496.

17. Thind CR, Desmond S, Harris O, Nadeem R, Chagla LS, Audisio RA: Radioguided localization of clinically occult breast lesions (ROLL): a DGH experience. Clin Radiol 2005, 60:681-6.

18. van Rijk MC, Tanis PJ, Nieweg OE, Loo CE, Olmos RA, Oldenburg HS, Rutgers EJ, Hoefnagel CA, Kroon BB: Sentinel node biopsy and concomitant probe-guided tumor excision of nonpalpable breast cancer. Ann Surg Oncol 2007, 14:627-32.
19. Moreno M, Wiltgen JE, Bodanese B, Schmitt RL, Gutfilen B, da Fonseca LM: Radioguided breast surgery for occult lesion localization - correlation between two methods. J Exp Clin Cancer Res 2008, 27:29.

20. Medina-Franco H, Abarca-Pérez L, García-Alvarez MN, Ulloa-Gómez JL, Romero-Trejo C, Sepúlveda-Méndez J: Radioguided occult lesion localization (ROLL) versus wire-guided lumpectomy for non-palpable breast lesions: a randomized prospective evaluation. J Surg Oncol 2008, 97:108-11.

21. Lavoué $V$, Nos $C$, Clough $K B$, Baghaie $F$, Zerbib E, Poulet B, Lefrère Belda MA, Ducellier A, Lecuru F: Simplified technique of radioguided occult lesion localization (ROLL) plus sentinel lymph node biopsy (SNOLL) in breast carcinoma. Ann Surg Oncol 2008, 15:2556-61.

22. Van Esser S, Hobbelink M, Ploeg Van der IM, Mali WP, Van Diest PJ, Borel Rinkes $\mathrm{IH}$, Van Hillegersberg R: Radio guided occult lesion localization (ROLL) for non-palpable invasive breast cancer. J Surg Oncol 2008, 98:526-9.

23. Sarlos D, Frey LD, Haueisen $H$, Landmann G, Kots LA, Schaer G: Radioguided occult lesion localization (ROLL) for treatment and diagnosis of malignant and premalignant breast lesions combined with sentinel node biopsy: a prospective clinical trial with 100 patients. Eur $J$ Surg Oncol 2009, 35:403-8.

24. Zgajnar J, Hocevar M, Frkovic-Grazio S, Hertl K, Schweiger E, Besic N: Radioguided occult lesion localization (ROLL) of the non palpable breast lesions. Neoplasma 2004, 51:385-9.

25. Nadeem R, Chagla LS, Harris O, Desmond S, Thind R, Titterrell C, Audisio RA: Occult breast lesions: A comparison between radioguided occult lesion localisation (ROLL) vs. wire-guided lumpectomy (WGL). Breast 2005, 14:283-9.

26. Rampaul RS, Bagnall M, Burrell H, Pinder SE, Evans AJ, Macmillan RD: Randomized clinical trial comparing radioisotope occult lesion localization and wire-guided excision for biopsy of occult breast lesions. Br J Surg 2004, 91:1575-7.

27. Ploeg van der IM, Hobbelink M, Bosch van den MA, Mali WP, Borel Rinkes $I H$, van Hillegersberg R: 'Radioguided occult lesion localisation' (ROLL) for non-palpable breast lesions: a review of the relevant literature. Eur J Surg Oncol 2008, 34:1-5.

28. Harlow SP, Krag DN, Ames SE, Weaver DL: Intraoperative ultrasound localization to guide surgical excision of nonpalpable breast carcinoma. J Am Coll Surg 1999, 189:241-6.

29. Smith LF, Rubio IT, Henry-Tillman R, Korourian S, Klimberg VS: Intraoperative ultrasound-guided breast biopsy. Am J Surg 2000, 180:419-23.

30. Kaufman CS, Jacobson L, Bachman B, Kaufman L: Intraoperative ultrasonography guidance is accurate and efficient according to results in 100 breast cancer patients. Am J Surg 2003, 186:378-82.

31. Bennet IC, Greenslade J, Chiam H: Intraoperative ultrasound-guided excision of nonpalpable breast lesions. World J Surg 2005, 29:369-74.

32. Ngô C, Pollet AG, Laperrelle J, Ackerman G, Gomme S, Thibault F, Fourchotte V, Salmon RJ: Intraoperative ultrasound localization of nonpalpable breast cancers. Ann Surg Oncol 2007, 14:2485-9.

33. Haid A, Knauer M, Dunzinger S, Jasarevic Z, Köberle-Wührer R, Schuster A, Toeppker M, Haid B, Wenzl E, Offner F: Intra-operative sonography: a valuable aid during breast-conserving surgery for occult breast cancer. Ann Surg Oncol 2007, 14:3090-101.

34. Fortunato L, Penteriani R, Farina M, Vitelli CE, Piro FR: Intraoperative ultrasound is an effective and preferable technique to localize nonpalpable breast tumors. Eur J Surg Oncol 2008, 34:1289-92.

35. Nagashima T, Hashimoto H, Oshida K, Nakano S, Tanabe N, Nikaido T, Koda K: Miyazaki M.Ultrasound demonstration of mammographic detected microcalcifications in patients with ductal carcinoma in situ of the breast. Breast Cancer 2005, 12:216-20.

36. Kurtz JM, Almaric R, Brandone H, Ayme Y, Jacquemier J, Pietra JC, Hans D, Pollet JF, Bressac C, Spitalier JM: Local recurrence after breast conserving surgery and radiotherapy. Cancer 1989, 63:1912-17.

37. Huston $T L$, Simmons RM: Locally recurrent breast cancer after conservation therapy. The American Journal of Surgery 2005, 189:229-235.

38. Komoike Y, Akiyama F, lino Y, Ikeda T, Akashi-Tanaka S, Ohsumi S, Kusama M, Sano M, Shin E, Suemasu K, Sonoo H, Taguchi T, Nishi T, Nishimura R, Haga S, Mise K, Kinoshita T, Murakami S, Yoshimoto M, Tsukuma $\mathrm{H}$, Inaji H: Ipsilateral breast tumor recurrence (IBTR) after breast- 
conserving treatment for early breast cancer: risk factors and impact on distant metastases. Cancer 2006, 106:35-41.

39. Lim W, Park EH, Choi SL, Seo JY, Kim HJ, Chang MA, Ku BK, Son B, Ahn SH: Breast conserving surgery for multifocal breast cancer. Ann Surg 2009, 249:87-90.

40. Jobsen JJ, Riemersa S, Palen van der J, Ong F, Jonkman A, Struikmar H: The impact of margin status in breast-conserving therapy for lobular carcinoma is age related. Eur J Surg col 2009.

41. Fourquet A, Campana F, Zafrani B, Mosseri V, Vielh P, Durand JC, Vilcoq JR: Prognostic factors of breast recurrence in the conservative management of early breast cancer: A 25-year follow-up. Int I Radiat Oncol Biol Phys 1989, 17:719-725.

42. Locker AP, Ellis IO, Morgan DA, Elston CW, Mitchell A, Blamey RW: Factors influencing local recurrence after excision and radiotherapy for primary breast cancer. Br J Surg 1989, 76:890-894.

43. Jobsen JJ, Palen van der J, Meerwaldt JH: The impact of age on local control in women with pT1 breast cancer treated with conservative surgery and radiation therapy. Eur J Cancer 2001, 37:1820-1827.

44. Antonini $\mathrm{N}$, Jones $\mathrm{H}$, Horiot JC, Poortmans P, Struikmans $\mathrm{H}$, Bogaert Van den W, Barillot I, Fourquet A, Jager J, Hoogenraad W, Collette L, Pierart M, Hart G, Bartelink H: Effect of age and radiation dose on local control after breast conserving treatment: EORTC trial 22881-10882. Radiother Oncol 2007, 82:265-71.

45. Dillon MF, Hill A, Quinn C, McDermott E, O'Higgins N: A pathologic assessment of adequate margin status in breast-conserving therapy. Annals Surg Oncol 2006, 13:333-339.

46. Jacobs L: Positive Margins: The Challenge Continues for Breast Surgeons. Ann Surg Oncol 2008, 15:1271-1272.

47. Bollet MA, Sigal-Zafrani B, Mazeau V: Age remains the first prognostic factor for loco-regional breast cancer recurrence in young ( $<40$ years) women treated with breast conserving surgery first. Radiother Oncol 2007, 82:272-80.

48. Renton SC, Gazet JC, Ford HT, Corbishley C, Sutcliffe R: The impact of the resection margin in conservative surgery for breast cancer. Eur I Surg Oncol 1996, 22:17-22.

49. Mansfield CM, Komarnicky LT, Schwartz GF, Rosenberg AL, Krishnan L, Jewell WR, Rosato FE, Moses ML, Haghbin M, Taylor J: Ten-year results in 1070 patients with stages I and II breast cancer treated by conservative surgery and radiation therapy. Cancer 1995, 75:2328-2336.

50. Singletary SE: Surgical margins in patients with early-stage breast cancer treated with breast conservation therapy. Am J Surg 2002, 184:383-393.

51. Smitt MC, Nowels K, Carlson RW, Stockdale FE, Goffinet DR: Predictor of reexcision findings and recurrence after breast conservation. Int I Radiot Oncol Biol Phys 2003, 57:979-985.

52. Clarke M, Collins R, Darby S, Davies C, Elphinstone P, Evans E, Godwin J, Gray R, Hicks C, James S, MacKinnon E, McGale P, McHugh T, Peto R, Taylor C, Wang Y: Early Breast Cancer Trialists' Collaborative Group (EBCTCG). Effects of radiotherapy and of differences in the extent of surgery for early breast cancer on local recurrence and 15-year survival: an overview of the randomized trials. Lancet 2005, 366:2087-106.

53. Fatouros M, Roukos DH, Arampatzis I, Sotiriadis A, Paraskevaidis E, Kappas AM: Factors increasing local recurrence in breast-conserving surgery. Expert Rev Anticancer Ther 2005, 5:737-45.

54. Fisher B, Anderson S, Fisher ER, Redmond C, Wickerham DL, Wolmark N, Mamounas EP, Deutsch M, Margolese R: Significance of ipsilateral breast tumour recurrence after lumpectomy. Lancet 1991, 338:327-331.

55. Arriagada R, Lê MG, Rochard F, Contesso G: Conservative treatment versus mastectomy in early breast cancer: patterns of failure with 15 years of follow-up data. Institut Gustave-Roussy Breast Cancer Group. $J$ Clin Oncol 1996, 14:1558-64.

56. Veronesi U, Saccozzi R, Del Vecchio M, Banfi A, Clemente C, De Lena M, Gallus G, Greco M, Luini A, Marubini E, Muscolino G, Rilke F, Salvadori B, Zecchini A, Zucali R: Comparing radical mastectomy with quadrantectomy, axillary dissection, and radiotherapy in patients with small cancers of the breast. N Engl J Med 1981, 305:6-11.

57. Fisher B, Anderson S, Bryant J, Margolese RG, Deutsch M, Fisher ER, Jeong $\mathrm{JH}$, Wolmark N: Twenty-year follow-up of a randomized trial comparing total mastectomy, lumpectomy, and lumpectomy plus irradiation for the treatment of invasive breast cancer. $N$ Engl J Med 2002, 347:1233-41
58. Blichert-Toft M, Rose C, Andersen JA, Overgaard M, Axelsson CK, Andersen KW, Mouridsen HT: Danish randomized trial comparing breast conservation therapy with mastectomy: six years of life-Table analysis. Consensus development conference on the treatment of early-stage breast cancer. Journal of the National Cancer Institute monographs. No. 11 Bethesda, Md.: National Cancer Institute 1992, 19-25.

59. van Dongen AJ, Voogd CA, Fentiman SI, Legrand C, Sylvester JR, Tong D, van der Schueren E, Helle AP, van Zijl K, Bartelink H: Long-Term Results of a Randomized Trial Comparing Breast-Conserving Therapy With Mastectomy: European Organization for Research and Treatment of Cancer 10801 Trial. JNCl Journal of the National Cancer Institute 2000, 92:1143-1150.

60. Straus K, Lichter A, Lippman M, Danforth D, Swain S, Cowan K, deMoss E, MacDonald H, Steinberg S, d'Angelo T: Results of the National Cancer Institute early breast cancer trial. J Natl Cancer Inst Monogr 1992, 11:27-32.

61. Fentiman IS: Long-term follow-up of the first breast conservation trial: Guy' wide excision study. Breast 2000, 5:8-9.

62. Fortin A, Larochelle M, Laverdiere J, Lavertu S, Tremblay D: Local failure is responsible for the decrease in survival for patients with breast cancer treated with conservative surgery and postoperative radiotherapy. J Clin Oncol 1999, 17:101-109.

63. Early Breast Cancer Trialists' Collaborative Group: Effect of radiotherapy and surgery in early breast cancer. An overview of the randomized trials. N Engl J Med 1995, 333:1444-55.

64. EBCTCG: Effects of radiotherapy and of differences in the extent of surgery for early breast cancer on local recurrence and on 15-year survival: an overview of the randomised trials. The Lancet 2005, 366:2087-2106.

65. Overgaard M, Hansen PS, Overgaard J, Rose C, Andersson M, Bach F, Kjaer M, Gadeberg CC, Mouridsen HT, Jensen MB, Zedeler K: Postoperative radiotherapy in high-risk premenopausal women with breast cancer who receive adjuvant chemotherapy. Danish Breast Cancer Cooperative Group 82b Trial. N Engl J Med 1997, 337:949-55.

66. Petit JY, Veronesi U, Luini A, Orecchia R, Rey PC, Martella S, Didier F, De Lorenzi F, Rietjens M, Garusi C, Sonzogni A, Galimberti V, Leida E, Lazzari R, Giraldo A: When mastectomy becomes inevitable: the nipple-sparing approach. Breast 2005, 14:527-31.

67. Chagpar AB: Skin-sparing and nipple-sparing mastectomy: preoperative, intraoperative, and postoperative considerations. Am Surg 2004, 70:425-32.

68. Toth BA, Lappert P: Modified skin incisions for mastectomy: the need for plastic surgical input in preoperative planning. Plastic and Reconstructive Surgery 1991, 87:1048-53.

69. Ho CM, Mak CK, Lau Y, Cheung WY, Chan MC, Hung WK: Skin involvement in invasive breast carcinoma: safety of skin-sparing mastectomy. Ann Surg Oncol 2003, 10:102-7.

70. Torresan RZ, dos Santos CC, Okamura H, Alvarenga M: Evaluation of residual glandular tissue after skin-sparing mastectomies. Ann Surg Oncol 2005, 12:1037-44.

71. Slavin SA, Schnitt SJ, Duda RB, Houlihan MJ, Koufman CN, Morris DJ, Troyan SL, Goldwyn RM: Skin-sparing mastectomy and immediate reconstruction: oncologic risks and aesthetic results in patients with early-stage breast cancer. Plast Reconstr Surg 1998, 102:49-62.

72. Newman LA, Kuerer HM, Hunt KK, Kroll SS, Ames FC, Ross MI, Feig BW, Singletary SE: Presentation, treatment, and outcome of local recurrence afterskin-sparing mastectomy and immediate breast reconstruction. Ann Surg Oncol 1998, 5:620-6.

73. Simmons RM, Fish SK, Gayle L, La Trenta GS, Swistel A, Christos P, Osborne MP: Local and distant recurrence rates in skin-sparing mastectomies compared with non-skin-sparing mastectomies. Ann Surg Oncol 1999, 6:676-81.

74. Kroll SS, Khoo A, Singletary SE, Ames FC, Wang BG, Reece GP, Miller MJ, Evans GR, Robb GL: Local recurrence risk after skin-sparing and conventional mastectomy: a 6-year follow-up Plast Reconstr Surg. 1999, 104:421-5.

75. Rivadeneira DE, Simmons RM, Fish SK, Gayle L, La Trenta GS, Swistel A, Osborne MP: Skin-sparing mastectomy with immediate breast reconstruction: a critical analysis of local recurrence. Cancer J 2000, 5:331-5.

76. Medina-Franco H, Vasconez LO, Fix RJ, Heslin MJ, Beenken SW, Bland KI, Urist MM: Factors associated with local recurrence after skin-sparing 
mastectomy and immediate breast reconstruction for invasive breast cancer. Ann Surg 2002, 235:814-9.

77. Foster RD, Esserman $\sqcup$, Anthony JP, Hwang ES, Do H: Skin-sparing mastectomy and immediate breast reconstruction: a prospective cohort study for the treatment of advanced stages of breast carcinoma. Ann Surg Oncol 2002, 9:462-6.

78. Carlson GW, Styblo TM, Lyles RH, Bostwick J, Murray DR, Staley CA, Wood WC: Local recurrence after skin-sparing mastectomy: tumor biology or surgical conservatism?. Ann Surg Oncol 2003, 10:108-12.

79. Greenway RM, Schlossberg L, Dooley WC: Fifteen-year series of skinsparing mastectomy for stage 0 to 2 breast cancer. Am J Surg 2005, 190:918-22.

80. Margulies AG, Hochberg J, Kepple J, Henry-Tillman RS, Westbrook K, Klimberg VS: Total skin-sparing mastectomy without preservation of the nipple-areola complex. Am J Surg 2005, 190:907-12.

81. Yano K, Hosokawa K, Masuoka T, Matsuda K, Takada A, Taguchi T, Tamaki Y, Noguchi S: Options for immediate breast reconstruction following skinsparing mastectomy. Breast Cancer 2007, 14:406-13.

82. Patani N, Devalia H, Anderson A, Mokbel K: Oncological safety and patient satisfaction with skin-sparing mastectomy and immediate breast reconstruction. Surg Oncol 2008, 17:97-105.

83. Scholz T, Kretsis V, Kobayashi MR, Evans GR: Long-term outcomes after primary breast reconstruction using a vertical skin pattern for skinsparing mastectomy. Plast Reconstr Surg 2008, 122:1603-11.

84. Ueda S, Tamaki Y, Yano K, Okishiro N, Yanagisawa T, Imasato M, Shimazu K, Kim SJ, Miyoshi Y, Tanji Y, Taguchi T, Noguchi S: Cosmetic outcome and patient satisfaction after skin-sparing mastectomy for breast cancer with immediate reconstruction of the breast. Surgery 2008, 143:414-25.

85. Garwood ER, Moore D, Ewing C, Hwang ES, Alvarado M, Foster RD, Esserman L: Total skin-sparing mastectomy: complications and local recurrence rates in 2 cohorts of patients. Ann Surg 2009, 249:26-32.

86. Gerber B, Krause A, Dieterich M, Kundt G, Reimer T: The oncological safety of skin sparing mastectomy with conservation of the nipple-areola complex and autologous reconstruction: an extended follow-up study. Ann Surg 2009, 249:461-8.

87. Bailey MH, Smith JW, Casas L, Johnson P, Serra E, de la Fuente R, Sullivan M, Scanlon EF: Immediate breast reconstruction: reducing the risks. Plast Reconstr Surg 1989, 83:845-51.

88. Noone RB, Murphy JB, Spear SL, Little JW: A 6-year experience with immediate reconstruction after mastectomy for cancer. Plast Reconstr Surg 1985, 76:258-69.

89. Woerdeman LA, Hage JJ, van Turnhout AA: Extended deepithelialization to secure double-breasted closure of the skin. Ann Plast Surg. 2005, 55:338-40.

90. Corral CJ, Mustoe TA: Controversy in breast reconstruction. Surg Clin North Am 1996, 76:309-26.

91. Krueger EA, Wilkins EG, Strawderman M, Cederna P, Goldfarb S, Vicini FA, Pierce L: Complications and patient satisfaction following expander/ implant breast reconstruction with and without radiotherapy. Int $J$ Radiat Oncol Biol Phys 2001, 49:713-21.

92. Taylor CW, Horgan K, Dodwell D: Oncological aspects of breast reconstruction. The Breast 2005, 14:118-130.

93. Persichetti P, Cagli B, Simone P, Cogliandro A, Fortunato L, Altomare V, Trodella L: Implant breast reconstruction after salvage mastectomy in previously irradiated patients. Ann Plast Surg 2009, 62:350-4.

94. Ascherman JA, Hanasono MM, Newman MI, Hughes DB: Implant reconstruction in breast cancer patients treated with radiation therapy. Plast Reconstr Surg 2006, 117:359-65.

95. Cordeiro PG, Pusic AL, Disa JJ, McCormick B, VanZee K: Irradiation after Immediate Tissue Expander/Implant Breast Reconstruction: Outcomes, Complications, Aesthetic Results, and Satisfaction among 156 Patients. Plast Reconstr Surg 2004, 113:877-81.

96. Paulhe P, Aubert JP, Magalon G: Forum on tissue expansion. Are tissue expansion and radiotherapy compatible? Apropos of a series of 50 consecutive breast reconstructions. Ann Chir Plast Esthet 1993, 38:54-61.

97. Santini D, Taffurelli M, Gelli MC, Grassigli A, Giosa F, Marrano D, Martinelli G: Neoplastic involvement of nipple-areolar complex in invasive breast cancer. Am J Surg 1989, 158:399-403.

98. Laronga C, Kemp B, Johnston D, Robb GL, Singletary SE: The incidence of occult nippleeareola complex involvement in breast cancer patients receiving skin-sparing mastectomy. Annals of Surgical Oncology 1999, 6:609-13.

99. Sikand K, Lee AH, Pinder SE, Elston CW, Ellis IO: Sections of the nipple and quadrants in mastectomy specimens for carcinoma are of limited value. Journal of Clinical Pathology 2005, 58:543-5.

100. Vlajcic Z, Zic R, Stanec S, Lambasa S, Petrovecki M, Stanec Z: Nipple-areola complex preservation: predictive factors of neoplastic nipple-areola complex invasion. Ann Plast Surg 2005, 55:240-4.

101. Petit JY, Veronesi U, Orecchia R, Luini A, Rey P, Intra M, Didier F, Martella S, Rietjens M, Garusi C, DeLorenzi F, Gatti G, Leon ME, Casadio C: Nipplesparing mastectomy in association with intra operative radiotherapy (ELIOT): A new type of mastectomy for breast cancer treatment. Breast Cancer Res Treat 2006, 96:47-51.

102. Gulben K, Yildirim E, Berberoglu U: Prediction of occult nipple-areola complex involvement in breast cancer patients. Neoplasma 2009, 56:72-5.

103. Sookhan N, Boughey JC, Walsh MF, Degnim AC: Nipple-sparing mastectomy-initial experience at a tertiary center. Am J Surg 2008, 196:575-7.

104. Brachtel E, Rusby J, Michaelson J, Chen L, Muzikansky A, Smith B, Koerner F: Occult Nipple Involvement in Breast Cancer: Clinicopathologic Findings in 316 Consecutive Mastectomy Specimens. JCO 2009, 27(30):4948-54.

105. Crowe JP Jr, Kim JA, Yetman R, Banbury J, Patrick RJ, Baynes D: Nipplesparing mastectomy: technique and results of 54 procedures. Arch Surg 2004, 139:148-50.

106. Caruso F, Ferrara M, Castiglione G, Trombetta G, De Meo L, Catanuto G, Carillio G: Nipple sparing subcutaneous mastectomy: sixty-six months follow-up. Eur J Surg Oncol 2006, 32:937-40.

107. Sacchini V, Pinotti JA, Barros AC, Luini A, Pluchinotta A, Pinotti M, Boratto MG, Ricci MD, Ruiz CA, Nisida AC, Veronesi P, Petit J, Arnone P, Bassi F, Disa JJ, Garcia-Etienne CA, Borgen PI: Nipple-sparing mastectomy for breast cancer and risk reduction: oncologic or technical problem?. J Am Coll Surg 2006, 203:704-14.

108. Komorowski AL, Zanini V, Regolo L, Carolei A, Wysocki WM, Costa A: Necrotic complications after nipple- and areola-sparing mastectomy. World J Surg 2006, 30:1410-3.

109. Stolier AJ, Sullivan SK, Dellacroce FJ: Technical considerations in nipplesparing mastectomy: 82 consecutive cases without necrosis. Ann Surg Oncol 2008, 15:1341-7.

110. Voltura AM, Tsangaris TN, Rosson GD, Jacobs LK, Flores Jl, Singh NK, Argani P, Balch CM: Nipple-sparing mastectomy: critical assessment of 51 procedures and implications for selection criteria. Ann Surg Oncol 2008, 15:3396-401.

111. Simmons RM, Hollenbeck ST, Latrenta GS: Two-year follow-up of areolasparing mastectomy with immediate reconstruction. Am J Surg 2004, 188:403-6.

112. Denewer A, Farouk O: Can Nipple-sparing Mastectomy and Immediate Breast Reconstruction with Modified Extended Latissimus Dorsi Muscular Flap Improve the Cosmetic and Functional Outcome among Patients with Breast Carcinoma?. World I Surg 2007, 31:1171-1179.

113. Crowe JP, Patrick RJ, Yetman RJ, Djohan R: Nipple-sparing mastectomy update: one hundred forty-nine procedures and clinical outcomes. Arch Surg 2008, 143:1106-10.

114. Gerber B, Krause A, Dieterich M, Kundt G, Reimer T: The oncological safety of skin sparing mastectomy with conservation of the nipple-areola complex and autologous reconstruction: an extended follow-up study. Ann Surg 2009, 249:461-8.

115. Petit JY, Veronesi U, Orecchia R, Rey P, Martella S, Didier F, Viale G, Luini A, Galimberti V, Bedolis R, Rietjens M, Garusi C, De Lorenzi F, Bosco R, Banconi A, Ivaldi GB, Youssef O: Nipple sparing mastectomy with nipple areola intraoperative radiotherapy: one thousand and one cases of a five years experience at the European Institute on oncology in Milan (IEO). Breast Cancer Res Treat 2009, 117:333-8.

116. Benediktsson KP, Perbeck L: Survival in breast cancer after nipple-sparing subcutaneous mastectomy and immediate reconstruction with implants: a prospective trial with 13 years median follow-up in 216 patients. Eur J Surg Oncol 2008, 249:143-8.

117. Rainsbury RM, Paramanathan N: UK survey of partial mastectomy and reconstruction. Breast 2007, 16:637-45.

118. Kaur N, Petit JY, Rietjens M, Maffini F, Luini A, Gatti G, Rey PC, Urban C, De Lorenzi F: Comparative study of surgical margins in oncoplastic surgery and quadrantectomy in breast cancer. Ann Surg Oncol 2005, 12:539-45. 
119. Fitzal F, Mittlboeck M, Trischler H, Krois W, Nehrer G, Deutinger M, Jakesz R, Gnant M: Breast-conserving therapy for centrally located breast cancer. Ann Surg 2008, 247:470-6.

120. Giacalone PL, Roger P, Dubon O, El Gareh N, Rihaoui S, Taourel P, Daurés JP: Comparative study of the accuracy of breast resection in oncoplastic surgery and quadrantectomy in breast cancer. Ann Surg Oncol 2007, 14:605-14.

121. Fisher ER, Gregorio RM, Fisher B: The pathology of invasive breast cancer. A syllabus derived from findings of the National Surgical Adjuvant Breast Project (protocol n. 04). Cancer 1975, 36:1-85.

122. Lagios MD, Gates EA, Westdahl PR, Richards V, Alpert BS: A guide to the frequency of nipple involvement in breast cancer: A study of 149 consecutive mastectomies using a serial subgross and correlated radiographic technique. Am J Surg 1979, 138:135-42.

123. Rosen PP, Fracchia AA, Urban JA, Schottenfield D, Robbins G: Residual mammary carcinoma simulated partial mastectomy. Cancer. 1975, 35:739-47.

124. Nogushi M, Earashi M, Kinoshita K, Taniya T, Miyazaki II: A case with breast cancer under the nipple who underwent breast conserving treatment. Breast Cancer 1994, 30:157-60.

125. Galimberti V, Zurrida S, Zanini V, Callegari M, Veronesi P, Catania S, Luini A, Greco M, Grisotti A: Central small size breast cancer: How to overcome the problem of nipple and areola involvement. Eur J Cancer 1993, 29:1093-6.

126. Haffty BG, Wilson LD, Smith R, Fischer D, Beinfield M, Ward B, McKhann C: Subareolar breast cancer: long-term results with conservative surgery and radiation therapy. Int J Radiat Oncol Biol Phys 1995, 33:53-7.

127. Simmons RM, Brennan MB, Christos P, Sckolnick M, Osborne M: Recurrence rates in patients with central or retroareolar breast cancers treated with mastectomy or lumpectomy. Am J Surg 2001, 182:325-9.

128. Pezzi CM, Kukora JS, Audet IM, Herbert SH, Horvick D, Richter MP: Breast conservation surgery using nipple-areolar resection for central breast cancers. Arch Surg 2004, 139:32-7.

129. Tausch C, Hintringer T, Kugler F, Schmidhammer C, Bauer $M$, Aufschnaiter M: Breast-conserving surgery with resection of the nippleareola complex for subareolar breast carcinoma. Br J Surg 2005, 92:1368-1371.

130. Naguib SF: Oncoplastic resection of retroareolar breast cancer: central quadrantectomy and reconstruction by local skin-glandular flap. J Egypt Natl Canc Inst 2006, 139:334-47.

131. Huemer GM, Schrenk P, Moser F, Wagner E, Wayand W: Oncoplastic techniques allow breast-conserving treatment in centrally located breast cancers. Plast Reconstr Surg 2007, 139:390-8.

132. Wagner E, Schrenk P, Huemer GM, Sir A, Schreiner M, Wayand W: Central quadrantectomy with resection of the nipple-areola complex compared with mastectomy in patients with retroareolar breast cancer. Breast $J$ 2007, 13:557-63.

133. Gajdos C, Tartter PI, Bleiweiss IJ: Subareolar breast cancers. Am J Surg 2000, 180:167-170

134. Dale PS, Giuliano AE: Nipple-areolar preservation during breastconserving therapy for subareolar breast carcinomas. Arch Surg 1996, 131:430-3

135. Fowble B, Solin LJ, Schultz DJ, Weiss MC: Breast recurrence and survival related to primary tumor location in patients undergoing conservative surgery and radiation for early stage breast cancer. Int JRadiat Oncol Biol Physic 1992, 23:933-9.

136. Harris JR, Lippman ME, Veronesi U, Willett W: Breast cancer. N Engl J Med 1992, 327:473-80.

137. Wilke LG, McCall LM, Posther KE, Whitworth PW, Reintgen DS, Leitch AM, Gabram SG, Lucci A, Cox CE, Hunt KK, Herndon JE, Giuliano AE: Surgical complications associated with sentinel lymph node biopsy: results from a prospective international cooperative group trial. Ann Surg Oncol 2006, 13:491-500.

138. Kim T, Giuliano AE, Lyman GH: Lymphatic mapping and sentinel lymph node biopsy in early-stage breast carcinoma. Cancer 2006, 106:4-16.

139. Cserni G, Amendoeira I, Apostolikas N, Bellocq JP, Bianchi S, Boecker W, Borisch B, Connolly CE, Decker T, Dervan P, Drijkoningen M, Ellis IO, Elston CW, Eusebi V, Faverly D, Heikkila P, Holland R, Kerner H, Kulka J, Jacquemier J, Lacerda M, Martinez-Penuela J, De Miguel C, Peterse JL, Rank F, Regitnig P, Reiner A, Sapino A, Sigal-Zafrani B, Tanous AM, Thorstenson S, et al: Discrepancies in current practice of pathological evaluation of sentinel lymph nodes in breast cancer. Results of a questionnairebased survey by the European Working Group for Breast Screening Pathology. J Clin Pathol 2005, 57:695-701.

140. Fortunato L, Amini M, Costarelli L, Piro FR, Farina M, Vitelli CE: A standardized sentinel lymph node enhanced pathology protocol (SEPP) in patients with breast cancer. J Surg Oncol 2007, 1(470):3-96.

141. Cronin-Fenton DP, Ries LA, Clegg LX, Edwards BK: Rising incidence rates of breast carcinoma with micrometastatic lymph node involvement. J Natl Cancer Inst 2007, 99:1044-9.

142. International (Ludwig) Breast Cancer Study Group: Prognostic importance of occult axillary lymph node micrometastases from breast cancers. Lancet 1990, 335:1565-8.

143. Dowlatshahi K, Fan M, Snider HC, Habib FA: Lymph node micrometastases from breast carcinoma: reviewing the dilemma. Cancer 1997, 80:1188-97.

144. Tan LK, Giri D, Panageas K: Occult micrometastases in axillary lymph nodes of breast cancer patients are significant: a retrospective study with long-term follow-up (abstract). Proc Am Soc Clin Oncol 2002, 21:37.

145. Colleoni M, Rotmensz N, Peruzzotti G, et al: Size of breast cancer metastases in axillary lymph nodes: clinical relevance of minimal lymph node involvement. J Clin Oncol 2005, 23:1379-89.

146. de Boer M, van Deurzen C, van Dijck J, Borm G, van Diest P, Adang E, Nortier J, Rutgers E, Seynaeve C, Menke-Pluymers M, Bult P, Tjan-Heijnen V: Micrometastases or isolated tumor cells and the outcome of breast cancer. NEJM 2009, 361:653-663.

147. Reynolds C, Mick R, Donohue JH, Grant CS, Farley DR, Callans LS, Orel SG, Keeney GL, Lawton TJ, Czerniecki BJ: Sentinel lymph node biopsy with metastasis: can axillary dissection be avoided in some patients with breast cancer?. J Clin Oncol 1999, 17:1720-6.

148. Turner RR, Chu KU, Qi K, Botnick LE, Hansen NM, Glass EC, Giuliano AE: Pathologic features associated with nonsentinel lymph node metastases in patients with metastatic breast carcinoma in a sentinel lymph node. Cancer 2000, 1(89):574-81.

149. Nos C, Harding-MacKean C, Fréneaux P, Trie A, Falcou MC, Sastre-Gara X, Clough KB: Prediction of tumour involvement in remaining axillary lymph nodes when the sentinel node in a woman with breast cancer contains metastases. Br J Surg 2003, 17:1354-60.

150. Hwang RF, Krishnamurthy S, Hunt KK, Mirza N, Ames FC, Feig B, Kuerer HM, Singletary SE, Babiera G, Meric F, Akins JS, Neely J, Ross MI: Clinicopathologic factors predicting involvement of nonsentinel axillary nodes in women with breast cancer. Ann Surg Oncol 2003, 10:248-54.

151. Fan YG, Tan YY, Wu CT, Treseler P, Lu Y, Chan CW, Hwang S, Ewing C, Esserman L, Morita E, Leong SP: The effect of sentinel node tumor burden on non-sentinel node status and recurrence rates in breast cancer. Ann Surg Oncol 2005, 12:705-11.

152. Rutledge H, Davis J, Chiu R, Cibull M, Brill Y, McGrath P, Samayoa L: Sentinel node micrometastasis in breast carcinoma may not be an indication for complete axillary dissection. Mod Pathol 2005, 18:762-8.

153. Schrenk P, Konstantiniuk P, Wölfl S, Bogner S, Haid A, Nemes C, JagoutzHerzlinger M, Redtenbacher S: Prediction of non-sentinel lymph node status in breast cancer with a micrometastatic sentinel node. $\mathrm{Br} J$ Surg 2005, 92:707-13.

154. van Rijk MC, Peterse JL, Nieweg OE, Oldenburg HS, Rutgers EJ, Kroon BB: Additional axillary metastases and stage migration in breast cancer patients with micrometastases or submicrometastases in sentinel lymph nodes. Cancer 2006, 1(107):467-71.

155. White RL Jr, Wilke LG: Update on the NSABP and ACOSOG breast cancer sentinel node trials. Am Surg 2004, 70:420-4.

156. Krag DN, Julian TB, Harlow SP, Weaver DL, Ashikaga T, Bryant J, Single RM, Wolmark N: NSABP-32: phase III randomized trial comparing axillary resection with sentinel lymph node dissection. A description of the trial. Ann Surg Oncol 2004, 11(Suppl 3):2085-10S.

157. National Cancer Institute, US National Institute of Health clinical trials, International Breast Cancer Study Group (IBCSG): Galimberti V Trial 23-01. Phase III randomized study of surgical resection with or without axillary lymph node dissection in women with a clinically node-negative breast cancer with a sentinel micrometastasis.http://www.cancer.gov/search/ ViewClinicalTrials.aspx?cdrid=67018\&version=healthprofessional.

158. Ernster VL, Ballard-Barbash R, Barlow WE, Zheng Y, Weaver DL, Cutter G, Yankaskas BC, Rosenberg R, Carney PA, Kerlikowske K, Taplin SH, Urban N, Geller BM: Detection of ductal carcinoma in situ in women undergoing screening mammography. Natl Cancer Inst 2002, 16(94):1546-54. 
159. Leonard GD, Swain SM: Ductal carcinoma in situ, complexities and challenges. J Natl Cancer Inst 2004, 96:906-20.

160. Zavagno G, Carcoforo P, Marconato R, Franchini Z, Scalco G, Burelli P, Pietrarota P, Lise M, Mencarelli R, Capitanio G, Ballarin A, Pierobon ME, Marconato G, Nitti D: Role of axillary sentinel lymph node biopsy in patients with pure ductal carcinoma in situ of the breast. BMC Cancer 2005, 5:28.

161. Veronesi $P$, Intra M, Vento AR: Sentinel lymph node biopsy for localized ductal carcinoma in situ?. Breast 2005, 14:520-2

162. Ansari B, Ogston SA, Purdie CA, Adamson DJ, Brown DC, Thompson A: Meta-analysis of sentinel node biopsy in ductal carcinoma in situ of the breast. Br J Surg 2008, 95:547-554.

163. Zavotsky J, Hansen N, Brennan MB, Turner RR, Giuliano AE: Lymph node metastasis from ductal carcinoma in situ with microinvasion. Cancer 1999, 85:2439-43.

164. Klauber-DeMore N, Tan LK, Liberman L, Kaptain S, Fey J, Borgen P, Heerdt A, Montgomery L, Paglia M, Petrek JA, Cody HS, Van Zee KJ: Sentinel lymph node biopsy: is it indicated in patients with high-risk ductal carcinoma-in-situ and ductal carcinoma-in-situ with microinvasion?. Ann Surg Oncol 2000, 7:636-42.

165. Wasserberg N, Morgenstern S, Schachter J, Fenig E, Lelcuk S, Gutman H: Risk factors for lymph node metastases in breast ductal carcinoma in situ with minimal invasive component. Arch Surg 2002, 137:1249-52.

166. Intra M, Zurrida S, Maffini F, Sonzogni A, Trifirò G, Gennari R, Arnone P, Bassani G, Opazo A, Paganelli G, Viale G, Veronesi U: Sentinel lymph node metastasis in microinvasive breast cancer. Ann Surg Oncol 2003, 10:1160-5

167. Le Bouëdec G, Gimbergues P, Feillel V, Penault-Llorca F, Dauplat : In situ mammary duct carcinoma with microinvasion. Which axillary lymph node exploration?. Presse Med 2005, 12(34):208-12.

168. Sakr R, Barranger E, Antoine M, Prugnolle H, Daraï E, Uzan S: Ductal carcinoma in situ: value of sentinel lymph node biopsy. I Surg Oncol 2006, 1(94):426-30.

169. Zavagno G, Belardinelli V, Marconato R, Carcoforo P, Franchini Z, Scalco G, Burelli P, Pietrarota P, Mencarelli R, Marconato G, Nitti D: Sentinel lymph node metastasis from mammary ductal carcinoma in situ with microinvasion. Breast 2007, 16:146-51.

170. Fortunato L, Santoni M, Drago S, Gucciardo G, Farina M, Cesarini C, Cabassi A, Tirelli C, Terribile D, Grassi GB, De Fazio S, Vitelli CE;: Rome Breast Cancer Study Group. Sentinel lymph node biopsy in women with pT1a or "microinvasive" breast cancer. Breast. 2008, 17:395-400.

171. Doyle B, Al-Mudhaffer M, Kennedy MM, O'Doherty A, Flanagan F, McDermot EW, Kerin MJ, Hill AD, Quinn CM: Sentinel lymph node biopsy in patients with a needle core biopsy diagnosis of DCIS - is it justified?. Clin Pathol 2009, 62:534-538.

172. Rubio IT, Roca I, Sabadell D, Xercavins J: Benefit of sentinel node biopsy in patients with breast ductal carcinoma in situ Cir Esp. 2009, 85:92-5.

173. Polom K, Murawa D, Wasiewicz J, Nowakowski W, Murawa P: The role of sentinel node biopsy in ductal carcinoma in situ of the breast. Eur J Surg Oncol 2009, 35:43-7.

174. van Deurzen $\mathrm{CH}$, Hobbelink MG, van Hillegersberg R, van Diest PJ: Is there an indication for sentinel node biopsy in patients with ductal carcinoma in situ of the breast? A review. Eur J Cancer 2007, 43:993-1001.

175. Veronesi U, Marubini E, Del Vecchio M, Manzari A, Andreola S, Greco M, Luini A, Merson M, Saccozzi R, Rilke F, Salvatori B: Local recurrences and distant metastases after conservative breast cancer treatments: partly independent events. J Natl Cancer Inst 1995, 4(87):19-27.

176. Sood A, Youssef IM, Heiba SI, El-Zeftawy H, Axelrod D, Seigel B, Mills C, Abdel-Dayem HM: Alternative lymphatic pathway after previous axillary node dissection in recurrent/primary breast cancer. Clin Nucl Med 2004, 29:698-702.

177. Agarwal A, Heron DE, Sumkin J, Falk J: Contralateral uptake and metastases in sentinel lymph node mapping for recurrent breast cancer. J Surg Oncol 2005, 92:4-8.

178. Roumen RMH, Kuijy GP, Liem LH: Lymphatic mapping and sentinel node harvesting in patients with recurrent breast cancer. Eur J Surg Oncol 2006, 32:1076-81.

179. Newman EA, Cimmino VM, Sabel MS, Diehl KM, Frey KA, Chang AE, Newman LA: Lymphatic mapping and sentinel lymph node biopsy for patients with local recurrence after breast-conservation therapy. Ann Surg Oncol 2006, 13:52-7.
180. Taback B, Nguyen P, Hansen N, Edwards GK, Conway K, Giuliano AE: Sentinel lymph node biopsy for local recurrence of breast cancer after breast-conserving therapy. Ann Surg Oncol 2006, 13:1099-104.

181. Intra M, Trifiro G, Galimberti V, Gentilini O, Rotmensz N, Veronesi P: Second axillary sentinel node biopsy for ipsilateral breast tumour recurrence. $\mathrm{Br}$ J Surg 2007, 94:1216-9.

182. Port ER, Garcia-Etienne CA, Park J, Fey J, Borgen PI, Cody HS: Reoperative sentinel lymph node biopsy: a newfrontier in th emanagement of ipsilateral breast tumor recurrence. Ann SurgOncol 2007, 14:2209-14.

183. Barone JL, Feldman SM, Estabrook A, Tartter PI, Rosenbaum Smith SM, Boolbol SK: Reoperative sentinel lymph node biopsy in patients with locally recurrent breast cancer. Am J Surg 2007, 194:491-3.

184. Axelsson CK, Jønsson PE: Sentinel lymph node biopsy in operations for recurrent breast cancer. Eur J Surg Oncol 2008, 34:626-30.

185. Koizumi M, Koyama M, Tada K, Nishimura S, Miyagi Y, Makita M, Yoshimoto M, Iwase T, Horii R, Akiyama F, Saga T: The feasibility of sentinel node biopsy in the previously treated breast. Eur J Surg Oncol 2008, 34:365-8.

186. Breslin TM, Cohen LF, Sahin A, Fleming JB, Kuerer HM, Newman LA, Delpassand ES, House R, Ames FC, Feig BW, Ross MI, Singletary SE, Buzdar AU, Hortobagyi GN, Hunt KK: Sentinel lymph node biopsy is accurate after neoadjuvant chemotherapy for breast cancer. $J$ Clin Oncol 2000, 18:3480-4

187. Tafra L, Verbanac KM, Lannin DR: Preoperative chemotherapy and sentinel lymphadenectomy for breast cancer. Am J Surg 2001, 182:312-5.

188. Fernandez A, Cortes M, Benito E, Azpeitia D, Prieto L, Moreno A, Ricart $Y$, Mora J, Escobedo A, Martín Comín J: Gamma probe sentinel node localization and biopsy in breast cancer patients treated with a neoadjuvant chemotherapy scheme. Nucl Med Commun 2001, 22:361-6.

189. Julian TB, Dusi D, Wolmark N: Sentinel node biopsy after neoadjuvant chemotherapy for breast cancer. Am J Surg 2002, 184:315-7.

190. Stearns V, Ewing CA, Slack R, Penannen MF, Hayes DF, Tsangaris TN: Sentinel lymphadenectomy after neoadjuvant chemotherapy for breast cancer may reliably represent the axilla except for inflammatory breast cancer. Ann Surg Oncol 2002, 9:235-42.

191. Brady EW: Sentinel lymph node mapping following neoadjuvant chemotherapy for breast cancer. Breast J 2002, 8:97-100.

192. Schwartz GF, Meltzer AJ: Accuracy of axillary sentinel lymph node biopsy following neoadjuvant (induction) chemotherapy for carcinoma of the breast. Breast J 2003, 9:374-9.

193. Piato JR, Barros AC, Pincerato KM, Sampaio AP, Pinotti JA: Sentinel lymph node biopsy in breast cancer after neoadjuvant chemotherapy. A pilot study. Eur J Surg Oncol 2003, 29:118-20.

194. Reitsamer R, Peintinger F, Rettenbacher L, Prokop E: Sentinel lymph node biopsy in breast cancer patients after neoadjuvant chemotherapy. J Surg Oncol 2003, 84:63-7.

195. Kang SH, Kim SK, Kwon Y, Kang HS, Kang JH, Ro J, Lee ES: Decreased identification rate of sentinel lymph node after neoadjuvant chemotherapy. World J Surg 2004, 28:1019-24.

196. Lang JE, Esserman LJ, Ewing CA, Rugo HS, Lane KT, Leong SP, Hwang ES: Accuracy of sentinel lymphadenectomy after neoadjuvant chemotherapy: effect of clinical node status at presentation. J Am Coll Surg 2004, 199:856-62.

197. Shimazu K, Tamaki Y, Taguchi T, Akazawa K, Inoue T, Noguchi S: Sentinel lymph node biopsy using periareolar injection of radiocolloid for patients with neoadjuvant chemotherapy-treated breast carcinoma. Cancer 2004, 100:2555-61.

198. Balch GC, Mithani SK, Richards KR, Beauchamp RD, Kelley MC: Lymphatic mapping and sentinel lymphadenectomy after preoperative therapy for stage II and III breast cancer. Ann Surg Oncol 2003, 10:616-21.

199. Mamounas EP, Brown A, Anderson S, Smith R, Julian T, Miller B, Bear HD, Caldwell CB, Walker AP, Mikkelson WM, Stauffer JS, Robidoux A, Theoret $H_{\text {, }}$ Soran A, Fisher B, Wickerham DL, Wolmark N: Sentinel node biopsy after neoadjuvant chemotherapy in breast cancer: results from National Surgical Adjuvant Breast and Bowel Project Protocol B-27. J Clin Oncol 2005, 23:2694-702.

200. Tausch C, Konstantiniuk P, Kugler F, Reitsamer R, Roka S, Pöstlberger S, Haid : A.Sentinel lymph node biopsy after preoperative chemotherapy for breast cancer: findings from the Austrian Sentinel Node Study Group. Ann Surg Oncol 2006. 
201. Newman EA, Sabel MS, Nees AV, Schott A, Diehl KM, Cimmino VM, Chang AE, Kleer C, Hayes DF, Newman LA: Sentinel lymph node biopsy performed after neoadjuvant chemotherapy is accurate in patients with documented node-positive breast cancer at presentation. Ann Surg Oncol 2007, 14:2946-52.

202. Shen J, Gilcrease MZ, Babiera GV, Ross MI, Meric-Bernstam F, Feig BW, Kuerer HM, Francis A, Ames FC, Hunt KK: Feasibility and accuracy of sentinel lymph node biopsy after preoperative chemotherapy in breast cancer patients with documented axillary metastases. Cancer 2007, 109:1255-63.

203. Kinoshita T: Sentinel lymph node biopsy is feasible for breast cancer patients after neoadjuvant chemotherapy. Breast Cancer 2007, 14:10-5.

204. Hino M, Sano M, Sato N, Homma K: Sentinel lymph node biopsy after neoadjuvant chemotherapy in a patient with operable breast cancer. Surg Today. 2008, 38:585-91.

205. Classe JM, Bordes V, Campion L, Mignotte H, Dravet F, Leveque J, Sagan C, Dupre PF, Body G, Giard S: Sentinel lymph node biopsy after neoadjuvant chemotherapy for advanced breast cancer: results of Ganglion Sentinelle et Chimiotherapie Neoadjuvante, a French prospective multicentric study. J Clin Oncol 2009, 27:726-32.

206. Schrenk P, Wayand W: Sentinel-node biopsy in axillary lymph node staging for patients with multicentric breast cancer. Lancet 2001, 357-122.

207. Fernandez K, Swanson M, Verbanac K: Is sentinel lymphadenectomy accurate in multifocal and multicentric breast cancer? [abstract 29]. Proceedings of the 55th Annual Cancer Symposium of the Society of Surgical Oncology 2002, S9-16.

208. Kumar R, Jana S, Heiba SI, Dakhel M, Axelrod D, Siegel B, Bernik S, Mills C, Wallack M, Abdel-Dayem HM: Retrospective analysis of sentinel node localization in multifocal, multicentric, palpable or non palpable breast cancer. J Nucl Med 2003, 44:7-10.

209. Tousimis E, Van Zee KJ, Fey JV, Hoque LW, Tan LK, Cody HS, Borgen PI, Montgomery LL: The accuracy of sentinel lymph node biopsy in multicentric and multifocal invasive breast cancers. J Am Coll Surg 2003, 197:529-35.

210. Goyal A, Newcombe RG, Mansel RE: Sentinel lymph node biopsy in patients with multifocal breast cancer. Eur J Surg Oncol 2004, 30:475-9.

211. Knauer M, Konstantiniuk P, Haid A, Wenzl E, Riegler-Keil M, Pöstlberger S, Reitsamer R, Schrenk P: Multicentric breast cancer: a new indication for sentinel node biopsyda multi-institutional validation study. J Clin Oncol 2006, 24:3374-80.

212. Ferrari A, Dionigi P, Rovera F, Boni L, Limonta G, Garancini S, De Palma D, Dionigi G, Vanoli C, Diurni M, Carcano G, Dionigi R: Multifocality and multicentricity are not contraindications for sentinel lymph node biopsy in breast cancer surgery. World J Surg Oncol 2006, 4:79-8.

213. Gentilini O, Trifiro' G, Soteldo J, Luini A, Intra M, Galimberti V, Veronesi P, Silva L, Gandini S, Paganelli G, Veronesi U: Sentinel lymph node biopsy in multicentric breast cancer. The experience of the European Institute of Oncology. Ann Surg Oncol 2006, 32:507-10.

214. D'Eredita G, Giardina C, Ingravallo G, Rubini G, Lattanzio V, Berardi T: Sentinel lymph node biopsy in multiple breast cancer using subareolar injection of the tracer. Breast 2007, 16:316-22.

215. Cipolla C, Vieni S, Fricano S, Cabibi D, Graceffa G, Costa R, Latteri S, Latteri MA: The accuracy of sentinel lymph node biopsy in the treatment of multicentric invasive breast cancer using a subareolar injection of tracer. World J Surg 2008, 32:2483-7.

216. Lo YF, Cheung YC, Hsueh S, Ho KC: Feasibility of sentinel lymph node biopsy in multifocal/multicentric breast cancer. Chang Gung Med J 2009, 32:51-8.

217. Veronesi U, Marubini E, Mariani L, Valagussa P, Zucali R: The dissection of internal mammary nodes does not improve the survival of breast cancer patients. 30-year results of a randomized trial. Eur J Cancer 1999, 35:1320-1325.

218. Estourgie SH, Nieweg OE, Valdes Olmos RA, Rutgers EJ, Kroon BB: Lymphatic drainage pattterns from the breast. Ann Surg 2004, 239:232-237.

219. Turner-Warwick RT: The lymphatics of the breast. Br J Surg 1959, 46:574-82.

220. Park C, Sied P, Morita E, Iwanaga K, Weinberg V, Quivey J, Hwang ES, Esserman LJ, Leong SP: Internal mammary sentinel lymph node mapping for invasive breast cancer: implications for staging and treatment. Breast J 2005, 11:29-33.
221. Paganelli G, Galimberti V, Trifirò G, Travaini L, De Cicco C, Mazzarol G, Intra $\mathrm{M}$, Rocca P, Prisco G, Veronesi U: Internal mammary node lymphoscintigraphy and biopsy in breast cancer. Q J NuCl Med 2002, 46:138-44.

222. Galimberti V, Veronesi P, Arnone P, De Cicco C, Renne G, Intra M, Zurrida S, Sacchini V, Gennari R, Vento A, Luini A, Veronesi U: Stage migration after biopsy of internal mammary chain lymph nodes in breast cancer patients. Ann Surg Oncol 2002, 9:924-8.

223. Farrus B, Vidal-Sicart S, Velasco M, Zanón G, Fernández PL, Muñoz M, Santamaría G, Albanell J, Biete A: Incidence of internal mammary node metastases after a sentinel lymph node technique in breast cancer and its implication in the radiotherapy plan. Int J Radiat Oncol Biol Phys 2004, 60:715-21.

224. Carcoforo P, Sortini D, Feggi L, Feo CV, Soliani G, Panareo S, Corcione S, Querzoli P, Maravegias K, Lanzara S, Liboni A: Clinical and therapeutic importance of sentinel node biopsy of the internal mammary chain in patients with breast cancer: a single-center study with long-term followup. Ann Surg Oncol 2006, 13:1338-43.

225. Spillane AJ, Noushi F, Cooper RA, Gebski V, Uren RF: High-resolution lymphoscintigraphy is essential for recognition of the significance of internal mammary nodes in breast cancer. Annali of Oncolology 2009, 20:977-984.

226. Heuts EM, Ent van der FWC, von Meyenfeldt MF, Voogd AC: Internal mammari lymph node drainage and sentinel node biopsyin breast cancer- A study on 1008 patients. EJSO 2009, 35:252-257.

227. Begg CB, Cramer LD, Hoskins WJ, Brennan MF: Impact of hospital volume on operative mortality for major cancer surgery. JAMA 1998, 280:1747-1751.

228. Hannan EL, O'Donnell JF, Kilburn H Jr, Bernard HR, Yazici A: Investigation of the relationship between volume and mortality for surgical procedures performed in New York State hospitals. JAMA 1989, 262:503-510.

229. Gordon TA, Burleyson GP, Tielsch JM, Cameron JL: The effects of regionalization on cost and outcome for one general high-risk surgical procedure. Ann Surg 1995, 221:43-9.

230. Simunovic $M$, To T, Langer B: Influence of hospital volume on mortality following major cancer surgery. JAMA 1999, 281:1374-5.

231. Glasgow RE, Showstack JA, Katz PP, Corvera CU, Warren RS, Mulvihill SJ: The relationship between hospital volume and outcomes of hepatic resection for hepatocellular carcinoma. Arch Surg 1999, 134:30-5.

232. Luft HS, Bunker JP, Enthoven AC: Should operations be regionalized? The empirical relation between surgical volume and mortality. $N$ Engl J Med 1979, 301:1364-9.

233. Farber BF, Kaiser DL, Wenzel RP: Relation between surgical volume and incidence of postoperative wound infection. N Engl J Med 1981, 305:200-4.

234. Fong $Y$, Gonen M, Rubin D, Radzyner M, Brennan MF: Long-term survival is superior after resection for cancer in high-volume centers. Ann Surg 2005, 242:540-4.

235. Guller U, Safford S, Pietrobon R, Heberer M, Oertli D, Jain NB: High hospital volume is associated with better outcomes for breast cancer surgery: analysis of 233,247 patients. World J Surg 2005, 29:994-9.

236. Gutierrez JC, Hurley JD, Housri N, Perez EA, Byrne MM, Koniaris LG: Are many community hospitals undertreating breast cancer?: lessons from 24,834 patients. Ann Surg 2008, 248:154-62.

237. Skinner KA, Helsper JT, Deapen D, Ye W, Sposto R: Breast cancer: do specialists make a difference?. Ann Surg Oncol 2003, 10(6):606-15.

238. Copeland EM III: Surgical oncology: a specialty in evolution. Ann Surg Oncol 1999, 6:424-32.

239. Cataliotti L, Costa A, Daly PA, Fallowfield L, Freilich G, Holmberg L, Piccart M, Velde van de CJ, Veronesi U: Florence Statement on Breast Cancer, 1998 Forging the Way Ahead for More Research on and Better Care in Breast Cancer. European Journal of Cancer 1999, 35:14-5.

240. The Hamburg Statement: The partnership driving the European agenda on breast cancer. European Journal of Cancer 2004, 40:1810-11.

doi:10.1186/1477-7819-8-5

Cite this article as: Mascaro et al:: Recent advances in the surgical care of breast cancer patients. World Journal of Surgical Oncology 2010 8:5. 